\title{
Reconsiderando a tese da penalidade neo- liberal: inclusão social e encarceramento em massa no Brasil
}

\author{
Reconsidering the neoliberal penality thesis \\ Social inclusion and mass incarceration in Brazil
}

iD) Luiz Phelipe Dal Santo ${ }^{1}$

Resumo: Com base na teoria de Loïc Wacquant, a ascensão do neoliberalismo é frequentemente considerada a principal causa do encarceramento em massa e do endurecimento das penas em diversos países. Embora inicialmente formulada para lidar com as transformações no sistema de justiça criminal estadunidense a partir dos anos 1970, a tese da "penalidade neoliberal" é frequentemente expandida para compreender prática punitivas tanto em países centrais, como em países periféricos. Esta também é uma prática comum na literatura criminológica brasileira. No entanto, as transformações político-econômicas e sociais verificadas no país nos últimos anos são aparentemente desconsideradas. Com base em análise de dados quantitativos sobre indicadores socioeconômicos como o IDH, o Índice de GINI e a taxa de desemprego - e investimento público em distintos setores (políticas penais e sociais), o caso brasileiro não apenas põe em xeque o suposto caráter universal da tese da penalidade neoliberal, como também identifica a necessidade de avançarmos o debate contemporâneo sobre punição para outras direções, para além do neoliberalismo.

Palavras-chave: Neoliberalismo; Encarceramento em massa; Loïc Wacquant; Pena; Inclusão social.

\footnotetext{
1 Doutorando em Criminologia pela Universidade de Oxford (Reino Unido). Mestre em Criminologia Crítica e Segurança Social pelas Universidades de Bolonha e Pádua (Itália). Pós-graduado em Direito Penal pela Universidade de Coimbra (Portugal). Graduado em Direito pela Universidade Presbiteriana Mackenzie. E-mail: luiz.dalsanto@crim.ox.ac.uk ID Lattes: 7985514812446945 ORCID: https://orcid.org/0000-0002-6576-3151
} 


\begin{abstract}
Based on Loïc Wacquant's theory, the rise of neoliberalism has been frequently considered the main cause of mass incarceration and the harshening of punishment around the world. Despite being firstly developed to explain the transformations in the US criminal justice system from the 1970s, the "neoliberal penalty thesis" is often expanded to provide an understanding of penal practices in both core and peripheral countries. This is also common in the Brazilian criminological literature. However, it seems that political, economic and social changes experienced in the country in the past years are often overlooked. Hence, by providing a more detailed account of the Brazilian case in the 21 st century, this paper aims to extend the criminological gaze and horizon beyond the core countries. Drawing on quantitative data of socioeconomic indicators - such as HDI, GINI index and unemployment rates - and public expenditure in different sectors (penal and social policies), the Brazilian case not only challenges reliance on the supposed universal character of the neoliberal penality thesis, but also identifies the necessity of moving the contemporary debate on punishment to other directions beyond neoliberalism.
\end{abstract}

Keywords: Neoliberalism; Mass incarceration; Loïc Wacquant; Punishment; Social inclusion.

Data de submissão do artigo: Outubro de 2019

Data de aceite do artigo: Junho de 2020 
Reconsiderando a tese da penalidade neoliberal inclusão social e encarceramento... Luiz Phelipe Dal Santo

\section{Introdução}

A partir das últimas décadas do século XX, uma tendência no sistema de justiça criminal passou a ser notada em diversas regiões do planeta. Ainda que com distinções quantitativas e qualitativas, verificou-se um considerável aumento na população carcerária e na taxa de encarceramento de grande parte dos países ao redor do mundo. Trata-se do encarceramento em massa.

Partindo da constatação de que o crescimento de uma população prisional não é mero reflexo do aumento do número de crimes cometidos, estudiosos e pesquisadores do sistema punitivo buscaram encontrar, em outros fatores, uma explicação para esta tendência. Neste quadro, amparado na teoria de Loïc Wacquant (2003a), o surgimento do neoliberalismo tem sido apontado como o principal elemento determinante do giro punitivo ${ }^{2}$, seja no debate global, seja no debate brasileiro sobre sociologia da punição. No entanto, é necessário destacar que o Brasil, a partir do século XXI, passou por um relevante momento de "social-liberalismo", o que se considera, ao menos preliminarmente, um aspecto antagônico à realidade neoliberal apresentada por Wacquant. Paralelamente, não houve qualquer alteração no ritmo acelerado da expansão do sistema penal brasileiro.

Este artigo busca analisar a compatibilidade da teoria da penalidade neoliberal em relação à realidade brasileira por meio de uma análise da variação de indicadores socioeconômicos e do investimento público em políticas penais e sociais. Trata-se especificamente de análise de dados oficiais disponibilizados por entidades e órgãos públicos, tais quais IBGE, IPEA e Ministério da Justiça.

Com o intuito de esclarecer o frequente desentendimento quanto ao próprio conceito "neoliberalismo", o primeiro tópico do presente artigo é pautado em uma retomada teórica, apontando três principais noções concedidas a tal conceito e identificando

2 Para um debate sobre a adequação da utilização de "giro punitivo" para descrever a realidade brasileira, ver Dal Santo (2019). 
Reconsiderando a tese da penalidade neoliberal inclusão social e encarceramento... Luiz Phelipe Dal Santo

aquela empregada por Wacquant, de modo a estabelecer uma base teórica mais sólida ou menos obscura. No segundo tópico, apresenta-se de fato a teoria da "penalidade neoliberal" de Wacquant, além de outras interpretações alternativas que, em qualquer medida, também vinculam o neoliberalismo ao incremento punitivo. No terceiro tópico, explora-se a ascensão do neoliberalismo e do encarceramento em massa no Brasil, a partir dos anos 1990. No quarto e último tópico, analisam-se o período social-liberal brasileiro - no qual o crescimento da população prisional e da taxa de encarceramento se manteve acelerado - e os efeitos do remodelamento político observado em tal momento, apontando, por fim, os limites à importação da teoria da penalidade neoliberal à realidade brasileira.

\section{Neoliberalismo: múltiplas faces de um conceito}

Inicialmente, é importante indicar que "neoliberalismo" é um conceito utilizado de variados modos, com significados diferentes e em contextos díspares, o que tende a gerar interpretações confusas, indevidas, mistificadas e muitas vezes contraditórias. Com efeito, este termo pode representar (i) uma política fundamentalmente econômica, (ii) um projeto político completo ou, ainda, (iii) uma nova racionalidade vinculada à governamentalidade foucaultiana. De modo geral, a condição hegemônica do neoliberalismo na atualidade é assumida nas três referidas acepções.

Segundo David Harvey (2008: 2),

o neoliberalismo é em primeiro lugar uma teoria das práticas político-econômicas que propõe que o bem-estar humano pode ser melhor promovido liberando-se as liberdades e capacidades empreendedoras individuais no âmbito de uma estrutura institucional caracterizada por sólidos direitos a propriedade privada, livres mercados e livre comércio. 
Reconsiderando a tese da penalidade neoliberal inclusão social e encarceramento... Luiz Phelipe Dal Santo

Equivocadamente costuma-se interpretar a função do Estado no modelo econômico neoliberal como simplesmente a não intervenção no sistema econômico, notadamente em razão de seu surgimento como um modelo de combate ao Estado intervencionista keynesiano, com um ideário anticomunista (ANDERSON: 1995). No desenvolvimento dos estudos criminológicos, esse primeiro conceito de "neoliberalismo" é adotado, por exemplo, por Cavadino e Dignan (2006), os quais o definem como uma política de liberalismo econômico baseada no capitalismo de livre mercado, cujas consequências são a ruptura do Welfare State e uma forte produção de desigualdade material e exclusão social. Resumidamente, o primeiro sentido concedido ao conceito de "neoliberalismo" é simplesmente uma economia de livre mercado.

Diferentemente da primeira interpretação acima indicada, a segunda vertente, mais ampla, sustenta que o modelo neoliberal não é apenas econômico, mas um sistema político completo. Compreende-se o Estado neoliberal para além do modelo liberal clássico de laissez-faire. Não se trata, de modo algum, de um Estado não intervencionista ou desmantelado, mas seu exato oposto. Há uma reengenharia do Estado que se mantém forte, todavia agora para facilitar as soluções de mercado, como sustentam Emma Bell (2011: 4; 2014: 53) e Loïc Wacquant (2012: 509-510). Sequer no âmbito da política econômica é possível verificar a "ausência" do Estado, o que representa, na realidade, uma "ilusão do livre mercado" (HARCOURT: 2011). Embora concordem acerca da existência de uma reestruturação do Estado e não de seu esvaziamento, Bell e Wacquant divergem quanto a um importante aspecto: enquanto a primeira sustenta inexistir um modelo uniforme e universalmente aplicável, haja vista a incidência das dimensões econômicas, sociais, políticas, legais, culturais e intelectuais diversas (BELL: 2011; 7), o segundo apresenta um modelo concreto que tem como base indissociável o vínculo estrutural entre o inchaço do sistema penal e o esvaziamento das políticas de assistência social (WACQUANT: 2003a; 2012; 2013). 
Reconsiderando a tese da penalidade neoliberal inclusão social e encarceramento... Luiz Phelipe Dal Santo

Por fim, o terceiro sentido empregado ao conceito "neoliberalismo" é associado à ideia de governamentalidade desenvolvida por Foucault (2014). Trata-se de uma racionalidade que contempla tecnologias e estratégias elaboradas tanto para governar populações, quanto para moldar indivíduos - sendo, portanto, mais do que uma ideologia, um sistema econômico ou um modelo político. Deste modo, há formas plurais e contínuas de governo - o governo político, o governo econômico, o governo da alma -, realizadas por distintas formas de poder que não se limitam ao âmbito público e são destinadas, em última instância, à produção de subjetividades individuais autorreguladas. A regulação do comportamento dos indivíduos é alcançada através de técnicas de governo e de poder direcionadas à intervenção no ambiente, de modo que a ação individual, a partir de respostas do próprio indivíduo, é sistematicamente adaptada e modulada para viver em um determinado meio. Trata-se, portanto, de uma sociedade governada mais pelo controle do que pela disciplina, haja vista que a contrapartida do exercício do poder disciplinar diretamente ao corpo do sujeito é o enfrentamento de maior resistência. Nessa conjuntura, investe-se nos controles reguladores, capazes de governar a população através do biopoder (FOUCAULT: 2008). Os indivíduos, aqui, são empresários de si mesmos, e o corpo social se assemelha cada vez mais à forma de empresa (FOUCAULT: 2008; 203 e 311).

De modo geral, costuma-se apresentar os governos de Margaret Thatcher, a partir de 1979, na Inglaterra, e de Ronald Reagan, dois anos depois, nos Estados Unidos, como as primeiras e principais representações de aplicação do modelo neoliberal nos países considerados como "de capitalismo avançado" - isto porque se aponta a ditadura de Pinochet (1973-1990), no Chile, como primeira experiência neoliberal conhecida no planeta -, tendo se espalhado pela Europa ao longo dos anos 80. Entre os seus destacados teóricos estão Friedrich Hayek, Milton Friedman e Ludwig Von Mises.

Quanto às suas características mais básicas e gerais - compreendidas principalmente nos dois primeiros modelos acima 
Reconsiderando a tese da penalidade neoliberal inclusão social e encarceramento... Luiz Phelipe Dal Santo

indicados -, pode-se falar em desterritorialização da produção, desregulamentação do trabalho, privatizações, declínio do modo de produção fordista e ascensão do modelo pós-fordista ${ }^{3}$, desemprego maciço estrutural e concentração do poder econômico gerando a concentração do poder político. Ainda, mesmo que de modo mais ou menos direto, reconhece-se o impacto do neoliberalismo (referente aos três distintos modelos acima apresentados) nos campos social, cultural e penal. Nota-se o desenvolvimento de uma cultura empresarial, a responsabilização do pobre por sua própria pobreza, a promoção desenfreada do individualismo e do consumismo, bem como a erosão da solidariedade social (CHOMSKY: 2006).

Portanto, não obstante existam diversas compreensões sobre o conceito "neoliberalismo", é imprescindível assimilar que as considerações realizadas por Loïc Wacquant são construídas a partir da ideia de "neoliberalismo realmente existe", o qual, segundo ele, se refere a um modelo político - isto é, não reduzido a um sistema econômico, nem ampliado a uma "racionalidade política maleável e mutável, que se adapta a muitos tipos de regimes e se insinua em todas as esferas da vida, sem nenhum fundamento externo consistente sobre o qual apoiar-se para opor-se a ela" (WACQUANT: 2012; 507).

\section{A penalidade neoliberal}

Conforme indicado anteriormente, o neoliberalismo é frequentemente apontado como o principal elemento responsável pelas mudanças e pelo endurecimento das políticas penais, representados sobretudo pelo encarceramento em massa. A teoria da penalidade neoliberal tem como seu principal teórico o francês Loïc Wacquant (2003a; 2012; 2013). Segundo Wacquant, pôde-se verificar, com a emergência do neoliberalismo, uma reengenharia do Estado, resultando no que o autor conceitua como "Estado

3 Ver mais em Giorgi (2002), Antunes (2006), Netto e Braz (2006). 
Reconsiderando a tese da penalidade neoliberal inclusão social e encarceramento... Luiz Phelipe Dal Santo

centauro", cuja cabeça é liberal e o corpo autoritário, isto é: liberal quanto às (causas e à constituição das) desigualdades sociais, libertador no topo da estrutura de classes, em favor dos detentores do capital; e intervencionista no que se refere aos considerados subalternos. No entanto, tal intervenção deixa de ser protetora, abandonando as políticas de bem-estar do Estado social (conforme Wacquant, mais bem classificado como Estado caritativo do que como Estado-providência), e passa a ser disciplinar, através do (i) workfare, no qual as políticas de assistência social aos pobres se tornam condicionais e coativas, uma vez que a concessão dos benefícios se vincula, na prática, à sujeição dos beneficiados aos subempregos; bem como através do (ii) prisonfare - âmbito este que mais interessa ao presente trabalho -, sendo compensada com a expansão do sistema penal e da criminalização da miséria (WACQUANT: 2001). A guerra contra a pobreza se transforma em guerra aos pobres, que são alçados ao posto de bode expiatório de todos os problemas sociais, econômicos e de ordem pública (WACQUANT: 2003; 24).

Para Wacquant (2012: 510; 2015: 17), o crescimento e fortalecimento do braço penal do Estado representa uma estrutura indissociável do Estado neoliberal. Os investimentos sociais e previdenciários dão lugar ao investimento em prisões e atividades de repressão. Tal afirmativa pode ser exemplificada com a irônica (e verdadeira) conclusão do sociólogo francês quanto ao fato de que a construção de penitenciárias se tornara o principal programa de habitação social dos Estados Unidos durante o governo de Ronald Reagan, na medida em que é constatada a inversão dos investimentos ${ }^{4}$ em habitação social e em construção de prisões (WACQUANT: 2003: 86). É necessário atentar-se ao fato de que a análise de Wacquant se refere, a princípio, à realidade estadunidense - muito embora o autor tenha posteriormente tratado do Brasil de modo específico em outras duas oportunidades (WACQUANT: 2003b; 2006).

4 Wacquant nota que, dez anos após a chegada de Reagan ao cargo de presidente dos EUA, os investimentos em habitação social passam de 27,4 bilhões para 10,6 bilhões de dólares. No mesmo período, o investimento em estabelecimentos prisionais vai de 6,9 bilhões para 26,1 bilhões de dólares (Wacquant: 2003a; 86). 
Reconsiderando a tese da penalidade neoliberal inclusão social e encarceramento... Luiz Phelipe Dal Santo

Nesse sentido, uma utilidade fundamental na opção da gestão penal da miséria em detrimento do precedente modelo assistencial é o fato de que

prender os pobres apresenta na verdade a imensa vantagem de ser mais 'visível' para o eleitorado: os resultados da operação são tangíveis e facilmente mensuráveis (tantos prisioneiros a mais); seus custos são pouco conhecidos e nunca submetidos a debate público, quando não são simplesmente apresentados como ganhos pelo fato de 'reduzirem' o custo do crime. 0 tratamento penal da pobreza é além disso dotado de uma carga moral positiva, enquanto a questão do 'welfare' está, desde o início, manchada pela imoralidade (Wacquant: 2003a; 86-87).

Esta opção, colocada em prática em uma conjuntura na qual a falácia da meritocracia é predominante, como se observa na ideologia neoliberal prevalecente, surgiria como uma política capaz de restaurar a autonomia e legitimidade do Estado perante a sociedade. Nota-se, aqui, uma funcionalidade simbólica do giro punitivo: o recrudescimento do sistema penal funciona para apaziguar a insegurança social crescente da classe média ${ }^{5}$. Todavia, é certo que o fortalecimento das instituições penais do Estado acompanha necessariamente as modificações implantadas no âmbito das políticas econômicas e sociais que ensejaram a intensificação da desigualdade de classes.

Outro elemento relevante na questão do encarceramento em massa é a composição da população carcerária, marcada pela sobrerrepresentação da população negra ${ }^{6}$, que é, ao mesmo tempo, componente inserido no campo das desigualdades sociais. De tal sorte, o encarceramento da população negra e marginalizada ser-

\footnotetext{
5 Não é demasiado sustentar que, entre o processo de importação e exportação de teorias criminológicas, este ponto do pensamento de Wacquant não foi devidamente recepcionado no Brasil, ou não recebeu a devida importância. Este fato pode ser (superficialmente) demonstrado, por exemplo, por meio dos nomes das versões traduzidas desta obra de Wacquant. Em português, o subtítulo concedido é: "a nova gestão da miséria nos Estados Unidos". Já nas versões em línguas italiana e inglesa é possível verificar este elemento simbólico relacionado à insegurança social enfatizado. Em italiano: “Il nuovo governo dell'insicurezza sociale". Em inglês: "the neoliberal government of social insecurity".

60 que também se verifica na realidade brasileira (cf. Dal Santo, 2017).
} 
Reconsiderando a tese da penalidade neoliberal inclusão social e encarceramento... Luiz Phelipe Dal Santo

ve também como ocultação da desigualdade social (WACQUANT: 2013; 57-80; GIORGI: 2016; 456).

A partir desta ótica, a prisão ocupa o posto de quarta instituição peculiar do controle do negro em uma ordem cronológica, que se inicia com a escravidão, dando lugar ao sistema legal de segregação racial (Jim Crow), que é substituído pelos guetos, os quais antecederam a instituição prisional.

"Gueto", para Wacquant (2003: 117), é "uma relação etnoracial de controle e de fechamento composta de quatro elementos: estigma, coação, confinamento territorial e segregação institucional". Sendo certo que os quatro supracitados elementos também se inserem na realidade prisional, o gueto é considerado uma prisão social, e a prisão considerada um gueto judiciário ${ }^{7}$, haja vista que o confinamento da população estigmatizada cumpre função de neutralizar ameaças tanto materiais quanto simbólicas por ela supostamente representadas à sociedade da qual tal população é segregada.

A substituição do gueto pelo cárcere, segundo sustentado por Wacquant, se relaciona igualmente com a onda de protestos e manifestações sociais da década de 60. A partir destes movimentos de reivindicação por direitos civis e sociais, uma nova ameaça negra à supremacia branca transforma o gueto estadunidense em uma instituição de contenção insuficiente e incapaz de controlar as emergentes "desordens" urbanas e movimentos de resistênciå.

Neste âmbito, Wacquant observa uma originalidade do cárcere enquanto instituição de controle e segregação. Diferentemente da escravidão, do Jim Crow e dos guetos, há uma ausência da relação econômica direta positiva, no sentido de recrutamento ou disciplina da mão de obra (WACQUANT: 2003a; 120). Este ponto difere inclusive do próprio enfoque primário da exploração dos prisioneiros a partir da relação direta entre encarceramento, lucro

\footnotetext{
7 Interessante notar que esta relação de equivalência ou semelhança entre o cárcere e uma certa instituição extramuros fora anteriormente feita por Dario Melossi e Massimo Pavarini, no entanto, comparando o cárcere à fábrica, e não ao gueto. Nesse sentido, segundo os criminólogos italianos, "a fábrica é para o operário como um cárcere (perda da liberdade e subordinação): o cárcere é para o interno como uma fábrica (trabalho e disciplina)" (Melossi; Pavarini: 2010; 266).

8 Michelle Alexander (2010) sustenta uma abordagem próxima a esta compreensão.
} 
Reconsiderando a tese da penalidade neoliberal inclusão social e encarceramento... Luiz Phelipe Dal Santo

econômico e disciplina da classe trabalhadora, que deu causa à emergência da instituição prisional (RUSCHE; KIRCHHEIMER, 2004; MELOSSI; PAVARINI: 2010).

Portanto, o encarceramento em massa é considerado por Wacquant uma consequência da reengenharia do Estado em seu projeto político neoliberal, no qual o esvaziamento do Estado social é vinculado ao inchaço do Estado penal, de modo diretamente ligado ao domínio das soluções de mercado na política econômica, produzindo forte aumento da desigualdade social e da marginalidade urbana. Há uma notável inversão do investimento em políticas de assistência e proteção aos vulneráveis para o investimento na repressão penal dos pobres e miseráveis. Dessa forma, o aparato penal produz politicamente uma realidade, definindo categorias de indivíduos, sustentando segregações materiais e simbólicas, impondo seletivamente a abertura a espaços sociais e físicos e, consequentemente, as relações sociais no interior de tais conjuntos.

Não por outro motivo, entre 1970 e 1991, a população carcerária dos Estados Unidos passa de 200 mil para 825 mil detentos, o que representa um crescimento de $314 \%$ em vinte anos (WACQUANT: 2003a; 28). Em 2000, o número de encarcerados chega a quase dois milhões, mantendo-se grande intensidade de crescimento (BECKETT; WESTERN: 2001; 43).

Por fim, o último elemento central na obra de Wacquant a ser aqui destacado diz respeito à difusão internacional das categorias e políticas penais importadas dos Estados Unidos (WACQUANT: 2001). Neste momento, a análise de Wacquant se refere ao encarceramento em massa para além dos Estados Unidos da América. Segundo Wacquant, a forte influência de Washington em relação à Europa e à América Latina, desde o plano econômico até o plano penal, produziria um trânsito transcontinental de políticas públicas que incidiriam na internacionalização da criminalização da miséria como nos moldes estadunidenses. 
Reconsiderando a tese da penalidade neoliberal inclusão social e encarceramento... Luiz Phelipe Dal Santo

Nesse sentido, a política de tolerância zero seria um símbolo de tal difusão inserida na importação de estratégias de segurança pública e de controle do crime, representando a atividade policial indispensável para o encarceramento em massa (WACQUANT: 2001). Segundo Alessandro de Giorgi (2000), trata-se mais de uma retórica política do que propriamente uma estratégia de segurança urbana bem definida. Este modelo (de retórica política ou de sistema de organização da atividade policial) tem sua origem na "teoria das janelas quebradas" (WILSON; KELLING: 1982), cujas consequências foram (i) a criminalização e a repressão de condutas banais, tais como a pichação e o grafite urbano, a mendicância, a embriaguez em lugar público, a lavagem de vidros e janelas de carros parados diante de semáforos fechados, entre outras infrações menores ou condutas que ofendiam supostamente a moralidade, a ordem pública e a qualidade de vida; (ii) o aumento substancial do efetivo policial; e (iii) a patrulha agressiva em zonas urbanas indicadas como de maior risco aos cidadãos.

Nesta conjuntura, haveria um modelo hegemônico de controle social e de estratégias de controle do crime, elaborado pela nação econômica, cultural e politicamente hegemônica (Estados Unidos da América), que seria posteriormente difundido pelos demais países (WACQUANT: 2001; BOURDIEU; WACQUANT: 2002; PAVARINI: 2002).

De modo geral, a ideia que vincula o aumento de práticas punitivas e o endurecimento das políticas penais, ensejando o maior encarceramento em locais nos quais governos investem menos em políticas de assistência e benefícios previdenciários, é sustentada também por Katherine Beckett e Bruce Western (2001), após análise dos estados estadunidenses, apontando o encarceramento em massa como o governo (penal e neoliberal) da marginalidade social.

Michael Cavadino e James Dignan (2006), de igual maneira, asseveram que a maior desigualdade em uma determinada sociedade produz um maior índice de punição, após exame de sistemas 
Reconsiderando a tese da penalidade neoliberal inclusão social e encarceramento... Luiz Phelipe Dal Santo

penais de diversos países capitalistas contemporâneos ${ }^{9}$, os quais foram categorizados em quatro modelos de economia política distintos, a partir da obra de Esping-Andersen (1990). Nos países classificados pelos autores como neoliberais - de capitalismo de livre mercado, minimização do welfare State, forte desigualdade material, exclusão social (não limitada à pobreza, mas também considerando direitos sociais e civis e participação na vida política e social) e estigmatização -, verificou-se a tendência a maiores taxas de encarceramento e a castigos mais severos. Contudo, os autores não desconsideram a importância das estruturas sociais históricas, da questão cultural em relação ao desvio e aos marginalizados e, sobretudo, não compreendem as "políticas de bem-estar social" limitadas às despesas sociais do Estado, mas sim como a cultura da sociedade em relação aos seus indivíduos.

Podem-se apontar, ainda, outros trabalhos que reconhecem a questão do giro punitivo de alguma forma associado ao Estado neoliberal, sem sustentarem, no entanto, uma relação estrutural imutável e mecânica do inchaço do sistema penal como extensão do sistema de bem-estar social (SUTTON: 2004; LACEY: 2008; BELL: 2010; 2014; CAVADINO; DIGNAN: 2011).

Emma Bell $(2010 ; 2014)$ compreende a expansão do sistema penal como uma questão política. Conforme indicado anteriormente, Bell não interpreta o neoliberalismo como um projeto exclusivamente de política econômica na qual o Estado deve ser reduzido ao máximo. De modo contrário, o Estado neoliberal deve ser intervencionista, porém direcionando suas ações à acumulação privada de riqueza (BELL: 2014; 57). Nesse sentido, uma solução encontrada para garantir legitimidade e apoio popular em um projeto político que funciona justamente em prejuízo da maior parte da população é através da política penal populista, ao mesmo tempo em que determina um bode expiatório específico (a "Clientela" do sistema penal), como responsável por todas as crises e problemas da sociedade.

9 Estados Unidos, Inglaterra e País de Gales, Austrália, Nova Zelândia, África do Sul, Alemanha, Holanda, França, Itália, Suécia, Finlândia e Japão. 
Reconsiderando a tese da penalidade neoliberal inclusão social e encarceramento... Luiz Phelipe Dal Santo

A utilização de estudos comparativos entre o sistema penal de países com diferentes economias políticas tem fundamental importância na sustentação do neoliberalismo como fator primordial no incremento punitivo.

John Sutton, analisando 15 países $^{10}$ entre 1960 e 1990, assevera que "as taxas de encarceramento são mais altas nos países onde as capacidades para regular a macroeconomia e a desigualdade contida são fracas" (SUTTON: 2004: 172, tradução livre). Segundo o autor em referência, além do aumento da desigualdade e da diminuição de políticas sociais distributivas, a estrutura institucional e a força e organização dos sindicatos são fundamentais na contenção ou intensificação dos índices de encarceramento, e estes são elementos que variam de acordo com o modelo corporativista ou liberal adotado.

Cavadino e Dignan (2011) posteriormente adaptaram o primeiro trabalho por eles realizado em 2006, atribuindo maior consideração à cultura das elites políticas e penais, bem como às instituições políticas do Estado, no entanto sempre dentro da perspectiva da economia política neoliberal.

Nicola Lacey (2008), por sua vez, partindo do mesmo tipo de estudo comparativo entre diferentes modelos de economia políti$\mathrm{ca}^{11}$, também chega à conclusão de que Estados de economia de mercado liberal apresentam maiores taxas de punitividade, ainda que por razões mais complexas do que a "simples" relação de diminuição de investimento em políticas welferistas e aumento em políticas penais. Para Lacey, há fundamental papel nas mediações realizadas por filtros cultural, econômico, político e institucional, que regulam a determinação de severidade penal e de políticas penais excludentes. A autora, no entanto, se distancia da tese de

\footnotetext{
10 Austrália, Canada, Nova Zelândia, Reino Unido e Estados Unidos (definidas como democracias anglo-americanas liberais); Dinamarca, Finlândia, Noruega e Suécia (social-democracias escandinavas); Áustria, Bélgica, França, Alemanha e Holanda (democracias corporativistas europeias).

11 Diferentemente de Cavadino e Dignan, que apontam quatro modelos diferentes de economia política (neoliberal, corporativista conservador, social democracia e corporativismo oriental), a autora parte de apenas dois tipos de economia política, indicados por Hall e Soskice (2003) como economia neoliberal e economia de mercado coordenado ou regulado. Basicamente, o conceito de "economia de mercado coordenado" engloba os modelos "corporativista conservador", "social democracia" e "corporativismo oriental" do trabalho de Cavadino e Dignan.
} 
Reconsiderando a tese da penalidade neoliberal inclusão social e encarceramento... Luiz Phelipe Dal Santo

Wacquant sobre a penalidade neoliberal, dizendo inclusive que esta deveria ser abandonada (LACEY: 2013; 277).

\section{Ascensão do neoliberalismo e encarceramento em massa no Brasil}

Após a experiência neoliberal chilena, México, Argentina e Peru também se adequaram às políticas neoliberais, todavia sem assumi-las como programa de governo nas campanhas eleitorais que antecederam tais imposições, as quais, na prática, foram obtidas mediante autoritarismos políticos (ANDERSON: 1995; 21). De todo modo, Perry Anderson (1995) sustenta haver uma alternativa para indução de políticas neoliberais de modo democrático e não coercitivo: a hiperinflação. Exatamente nesse sentido, verifica-se um ciclo de inflação explosiva no Brasil entre 1970 e 1995, atingindo uma taxa anual de 2.737\% em 1990 (IBGE: 2006; 514).

O projeto neoliberal no Brasil se iniciou em 1989, com a eleição de Fernando Collor de Mello, cuja proposta de modernização do Estado brasileiro equivalia "à integração subordinada do Brasil nos marcos do mundo capitalista avançado" (ANTUNES: 2005; 16), colocando em prática, por exemplo, o Programa Nacional de Desestatização, assumido pela Lei n 8.031 , de 12 de abril de 1990, definindo claramente o plano de privatizações e permitindo a venda de empresas públicas ao capital internacional e às empresas multinacionais.

A partir deste momento, destaca-se também a formulação do Consenso de Washington, um conjunto de políticas públicas, e sua adoção como política oficial do Fundo Monetário Internacional (FMI), o qual recomendava sua implementação, com a promessa de retomar o desenvolvimento, elevar a competitividade e reduzir a pobreza das economias latino-americanas (MARTINS: 2011; 319). Este programa de desenvolvimento consistia em dez recomendações: disciplina fiscal; contenção de gastos públicos, priorizando 
Reconsiderando a tese da penalidade neoliberal inclusão social e encarceramento... Luiz Phelipe Dal Santo

saúde e educação; reforma tributária; aumento de taxas de juros; fixação de câmbio comercial competitivo; desmonte de barreiras tarifárias e liberalização de políticas comerciais; abertura para investimentos estrangeiros diretos; privatização de empresas públicas; desregulamentação econômica; e proteção à propriedade privada (MARTINS: 2011; 319).

A intensificação do neoliberalismo brasileiro, no entanto, foi promovida por Fernando Henrique Cardoso, notadamente a partir da submissão às "recomendações" financeiras do Conselho de Washington, do FMI, e do Banco Mundial.

O que se verificou ao longo da década de 1990 foi, de fato, a desnacionalização da economia, a privatização, a desindustrialização, a precarização, a terceirização e a informalização do trabalho, entre outras características da política econômica neoliberal.

Carlos Eduardo Martins aponta alguns fatores que indicam a clara e intensa desnacionalização da economia brasileira neste período. Primeiramente, o autor aponta que a dívida externa, que estava em 30,4\% do PIB nacional em 1991, atinge 43\% do PIB em 2001 (MARTINS: 2005; 152). Ao mesmo tempo, pôde-se verificar uma intensa investida do capital estrangeiro nos ativos nacionais, saltando de $14,8 \%$ das receitas das empresas líderes brasileiras em 1991 para 36,4\% em 1999 (MARTINS: 2005; 153). Segundo Martins, este crescimento é reflexo de dois principais fatores: a redução da participação das empresas estatais, com a redução de suas receitas de $44,6 \%$ para $24,3 \%$ neste período; e a expansão das empresas multinacionais inclusive sobre as empresas brasileiras nacionais a partir da segunda metade da década de 1990, notadamente nos setores industrial e de serviços (MARTINS: 2005; 153).

Quanto às privatizações de empresas públicas, estas foram realizadas nos mais diversos campos econômicos, englobando empresas de energia elétrica, de telecomunicações, estradas, previdência, e até mesmo empresas de grande relevo em escala global, tal qual a Vale do Rio Doce (ANTUNES: 2005; 38). 
Reconsiderando a tese da penalidade neoliberal inclusão social e encarceramento... Luiz Phelipe Dal Santo

Outra consequência comum às políticas econômicas neoliberais também verificada no Brasil é a destruição do setor produtivo da economia. A indústria manufatureira, por exemplo, a qual representava 33,6\% do PIB em 1980, passou a equivaler a 19,8\% em 2000 (MARTINS: 2005; 153). Em sentido diverso, apenas o setor terciário aumentou sua participação no Produto Interno Bruto brasileiro (POCHMANN: 2012; 17).

Ademais, é possível identificar algumas consequências no mundo do trabalho que, uma vez mais, manifestam a adequação da economia brasileira às políticas neoliberais "recomendadas" pelo FMI e pelo Banco Mundial.

A informalização e a terceirização do trabalho são algumas características padrões da economia neoliberal intensificadas justamente a partir da década de 1990 (ANTUNES: 2005; 2014; POCHMANN: 2012), de modo que o trabalho informal atingia $60 \%$ do total de trabalhadores no Brasil em 2003 (ANTUNES: 2005; 149). Segundo verificado por Marcio Pochmann (2012: 38), houve uma redução de mais de 260 mil postos de trabalho assalariado formal no trabalho de salário base (em até um salário mínimo e meio) nos anos 1990. Nesta década, mais da metade dos empregos gerados não previa remuneração (POCHMANN: 2012; 27).

Em relação à terceirização do trabalho, no período entre 1985 e 1995, o número de trabalhadores terceirizados aumentou em uma média de $9 \%$ ao ano, ao mesmo tempo em que o número de empresas de terceirização cresceu 22,5\%, igualmente em média anual (POCHMANN: 2012; 111). A expansão do trabalho terceirizado ocorreu de forma ainda mais intensa a partir de 1996 (POCHMANN: 2012; 111-112), acarretando evidente precarização das condições de trabalho.

Outro aspecto marcante dos anos 1990 no Brasil é o crescimento do desemprego. Entre dezembro de 1991 e dezembro de 1999, houve um aumento superior a 50\% em referência à porcentagem de desemprego no país ${ }^{12}$. Este crescimento do desemprego

12 Dados disponíveis em: https://seriesestatisticas.ibge.gov.br/series.aspx?vcodigo=FDT10\&t=taxa-de-desemprego-aberto-das-pessoas-de-15-anos-e-mais-de-idade-referencia-30-dias. Acesso em: 26 set. 2017. 
Reconsiderando a tese da penalidade neoliberal inclusão social e encarceramento... Luiz Phelipe Dal Santo

brasileiro é ainda mais impressionante quando dimensionado em perspectiva global. Em 1986, o desemprego brasileiro representava $1,68 \%$ do desemprego global - equivalendo ao $13^{\circ}$ lugar entre todas as nações -, enquanto o país possuía 2,75\% da População Economicamente Ativa (PEA). Já em 1999, o Brasil ocupava o terceiro posto no ranking de desemprego global, equivalendo a 5,61\% do total de desemprego no planeta, ao passo em que sua PEA não cresceria na mesma proporção, atingindo 3,12\% da PEA global (ANTUNES: 2005; 136).

Por fim, de modo associado ao cenário das relações de trabaIho acima indicado e à histórica concentração de renda no Brasil, é possível apresentar uma última característica do quadro socioeconômico relativo ao período em referência. Trata-se da diminuição do rendimento do trabalho e do simultâneo incremento das rendas de propriedade (lucros, juros, renda de terra e aluguéis) na formação do total da renda nacional (POCHMANN: 2012; 9-15).

Nestes termos, é notório o fato de que a ascensão do neoliberalismo no Brasil produziu severos efeitos sociais e econômicos, gerando limitações à então recente democracia brasileira. Consequentemente, desde o final dos anos 1980 e durante toda a década de 1990, o Brasil continuou sendo o país mais desigual da América Latina ${ }^{13}$ e um dos mais desiguais de todo o mundo ${ }^{14}$.

De todo modo, as limitações impostas à concessão e à efetivação de direitos na década de 1990 não se restringiam apenas ao plano econômico, mas se estruturavam também a partir da expansão do sistema penal brasileiro. Atribui-se justamente a este período a origem do encarceramento em massa no Brasil.

A partir dos anos 1990, identifica-se um enorme aumento tanto no número absoluto da população prisional brasileira, quanto no número proporcional referente à taxa de encarceramento. Nesse sentido, enquanto aproximadamente 90.000 pessoas encontravam-se presas no Brasil em 1990, representando uma taxa de encarceramento de 61 presos a cada 100 mil habitantes, cerca

13 Disponível em: https://ourworldindata.org/income-inequality/. Acesso em: 01 out. 2017.

14 Disponível em: https://data.worldbank.org/indicator/SI.POV.GINI?end=1999\&start=1986. Acesso em: 01 out. 2017. 
Reconsiderando a tese da penalidade neoliberal inclusão social e encarceramento... Luiz Phelipe Dal Santo

de 239.300 detentos integravam a população carcerária brasileira em 2002, atingindo uma taxa de encarceramento de 137, nos mesmos termos acima indicados (MINISTÉRIO DA JUSTIÇA, 2017). Trata-se, portanto, de um aumento de $165,9 \%$ em relação à população prisional em absoluto, e de $124,6 \%$ referente à taxa de encarceramento, em um período de 12 anos.

Neste período, podem-se destacar, ainda, outras características equiparadas a elementos constitutivos do "giro punitivo" para além do aumento absoluto e relativo de pessoas encarceradas, como o surgimento de "legislações draconianas" e do "transencarceramento".

O primeiro elemento se refere especialmente à Lei dos Crimes Hediondos - Lei n. 8.072/90 -, cujo surgimento é vinculado a uma considerável pressão midiática. ${ }^{15}$ Efetivamente, tal lei impactou no aumento da população carcerária por diversos modos, como por meio das proibições da liberdade provisória, da fiança, da anistia, da graça, do indulto e da progressão de regime ou, ainda, pela determinação do cumprimento de pena integralmente em regime fechado para específicos crimes (dentre os quais o tráfico de drogas), os quais também tiveram os limites mínimo e máximo de suas penas-base aumentados.

O segundo elemento, por sua vez, corresponde ao inchaço do sistema penal não limitado ao encarceramento em massa, compreendendo também a expansão de aplicação de penas e medidas alternativas ao cárcere. De tal sorte, enquanto em 1987 foram registradas apenas 197 penas alternativas, no ano de 2002 foram contabilizadas 102.403 penas e medidas alternativas aplicadas (MINISTÉRIO DA JUSTIÇA: 2010; 16-17).

Não há como se negar, portanto, as consideráveis semelhanças entre a realidade brasileira da década de 1990 e o contexto teórico referente à teoria da penalidade neoliberal.

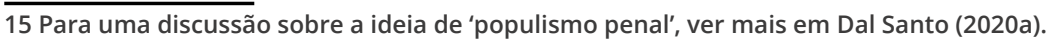


Reconsiderando a tese da penalidade neoliberal inclusão social e encarceramento... Luiz Phelipe Dal Santo

\section{Os limites da penalidade neoliberal}

O contexto brasileiro descrito até aqui permite compreender a razão pela qual a penalidade neoliberal se estabelece como a teoria crítica mais difundida para explicar o giro punitivo e principalmente o encarceramento em massa no Brasil. Conforme indicado, o crescimento na taxa de encarceramento no Brasil é intensificado justamente no período de ascensão do neoliberalismo no país, notadamente nos anos 1990, sendo contemporâneo ao processo de desindustrialização e privatização, assim como ao aumento do desemprego e à precarização, à terceirização e à informalização do trabalho.

De todo modo, algumas contradições e incompatibilidades deveriam ser expostas e esclarecidas para a incorporação de tal teoria à realidade brasileira, o que, em regra, não é verificado na literatura criminológica brasileira.

O primeiro ponto a se destacar é a importância da transição de modelos políticos. Wacquant (2003a) é claro ao sustentar que o Estado penal é estabelecido após o abandono ao Estado social ou ao Welfare State. Não por outra razão, nota-se que uma incompatibilidade em relação à realidade brasileira é exatamente o fato de que o Brasil jamais viveu sob um regime de Welfare. Em sentido contrário, o país vivia sob um regime de ditadura militar, marcado por terrorismo de Estado, pela tortura institucionalizada como método de obtenção de prova, por prisões ilegais, arbitrárias e "para investigação", pelo desaparecimento de mortos políticos, pela censura, entre outras características que constituem uma realidade fundamentalmente distante de qualquer ideário de inclusão social, de solidariedade, de cidadania, de vida coletiva e de efetivação de amplos direitos sociais, políticos e civis em geral. Ademais, embora o período entre 1960 e 1980 tenha sido marcado pela ampliação da taxa de ocupação da mão de obra - e também pela maior formalização do emprego (POCHMANN: 2012) -, a valoração das condições de vida da classe trabalhadora exclusivamente medida 
Reconsiderando a tese da penalidade neoliberal inclusão social e encarceramento... Luiz Phelipe Dal Santo

por meio da taxa de desemprego é insuficiente (SUTTON, 2004; GIORGI, 2016A; BRANDARIZ GARCÍA; MELOSSI; SOZZO, 2017). De tal modo, destaca-se que, durante este mesmo período, o nível de desigualdade na distribuição de renda do trabalho aumentou mais de 20\% (POCHMANN: 2012; 14). Fora isso, o período da ditadura militar foi marcado também pelo fechamento de sindicatos e por perseguições a líderes operários e camponeses, a comunistas, a anarquistas e a partidos de esquerda. É evidente, portanto, a enorme divergência quanto às realidades política, social e econômica no período anterior à ascensão do neoliberalismo no Brasil em relação à realidade de bem estar social estadunidense (e europeia).

No entanto, embora o período "pré-neoliberal" seja relevante, a mais problemática contradição e com maior demanda de análise se refere justamente à existência de um período muitas vezes classificado como "pós-neoliberal". Trata-se de um período de consideráveis mudanças nos campos político, econômico e social vivenciadas no Brasil ao longo do século XXI, notadamente a partir dos governos nacionais pelo Partido dos Trabalhadores, desde o presidente Lula à presidente Dilma.

Análises de economia política mais radicais à esquerda sustentam a inexistência da ruptura profunda com o sistema neoliberal durante esta época, apontando para mudanças sobretudo conjunturais, classificando tal período como social-liberal (ANTUNES: 2005; 2013; 2015). Por outro lado, há aqueles que sustentam a existência de mudanças estruturais, sendo o suficiente para classificar este período como pós-neoliberal (SADER: 2013).

Não obstante este debate seja relevante, por ora será suficiente apontar o desenvolvimento econômico conciliado às políticas sociais, cujos efeitos foram a diminuição do desemprego - inclusive por meio de criação de postos de trabalho majoritariamente formal -, a grande redução absoluta da extrema pobreza no Brasil e a diminuição da taxa de desigualdade de renda.

Antes, porém, é importante expor o quadro do sistema penal no período a ser agora analisado, isto é, entre 2002 e 2014. 
Reconsiderando a tese da penalidade neoliberal inclusão social e encarceramento... Luiz Phelipe Dal Santo

Não obstante o último Levantamento Nacional de Informações Penitenciárias informe dados até dezembro de 2016, considera-se mais adequado restringir este lapso temporal até 2014 por dois motivos. A primeira razão é meramente matemática: o primeiro período analisado (o neoliberal) vai de 1990 a 2002, correspondendo a 12 anos; não por outro motivo, é mais coerente realizar uma análise comparativa que incorpore dois períodos temporais equivalentes. Ademais, verifica-se certa deterioração econômica e social no país a partir de 2015. Dito isso, retoma-se a análise do desenvolvimento do sistema penal brasileiro no período de "inclusão social".

A população prisional brasileira, a qual totalizava 239.300 presos em 2002, passou a um total de 622.000 presos em 2014, representando um aumento de 159,9\%. Já em relação à taxa de encarceramento, que transitou de 137 para 306 no mesmo período, verifica-se um aumento de $123,4 \%$.

Nestes termos, a imagem seguinte (Gráfico 1) indica um quadro de contínuo, intenso e acelerado crescimento da população prisional brasileira, seja em termos relativos (taxa de encarceramento) ou absolutos, tanto no período neoliberal, quanto no período de inclusão social. 
Reconsiderando a tese da penalidade neoliberal inclusão social e encarceramento... Luiz Phelipe Dal Santo

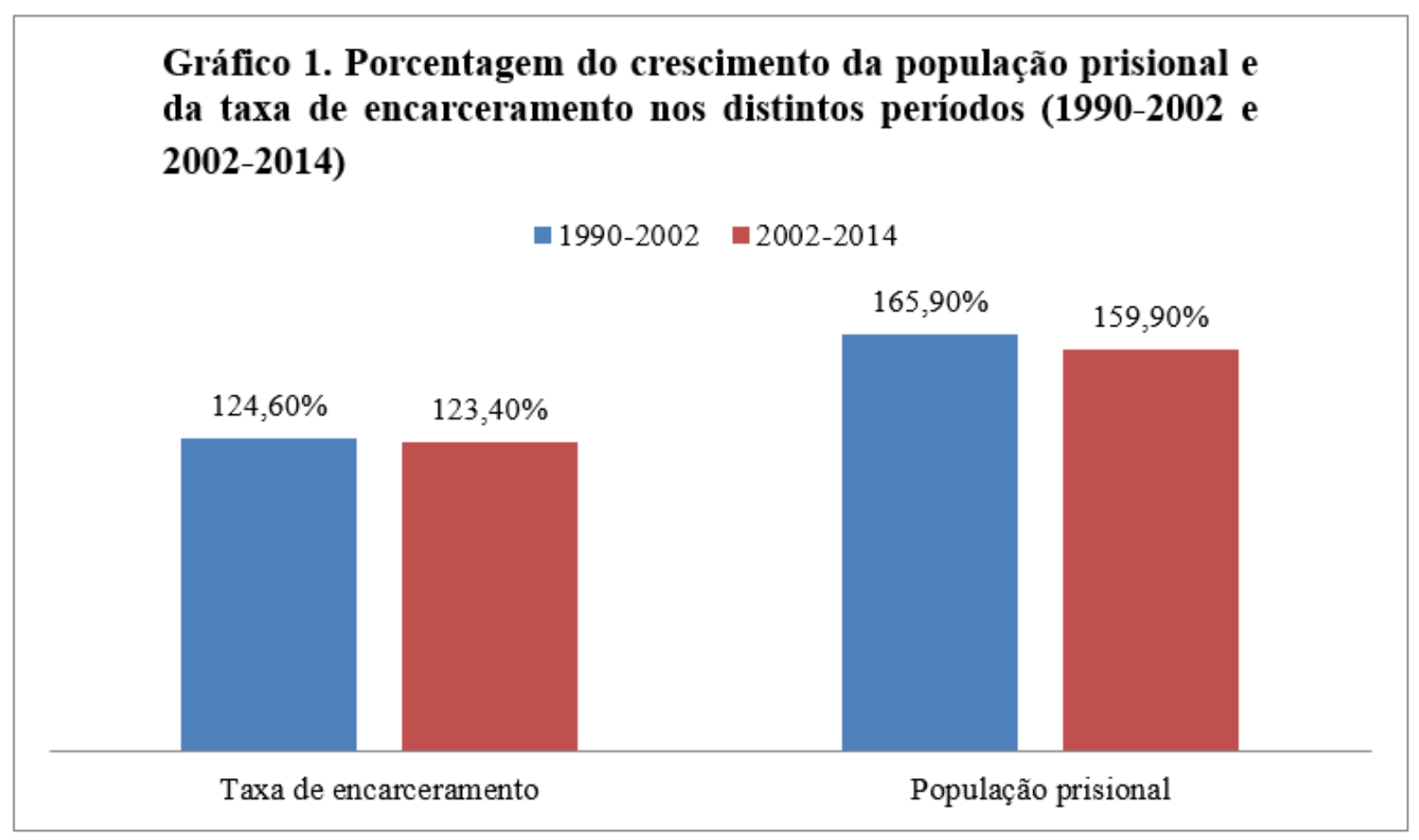

Fonte: Ministério da Justiça (2016; 2017).

Em que pese o retrato do sistema de justiça criminal nos dois diferentes períodos indique continuidade e semelhança, o cenário político, econômico e social apresenta consideráveis rupturas e distinções. O primeiro possível medidor da melhora nas condições de vida no Brasil é a análise da variação do Índice de Desenvolvimento Humano (IDH), o qual saiu de 0,611 em 1990 para atingir 0,754 em 2015, conforme indicado no gráfico seguinte (Gráfico 2). 
Reconsiderando a tese da penalidade neoliberal inclusão social e encarceramento... Luiz Phelipe Dal Santo

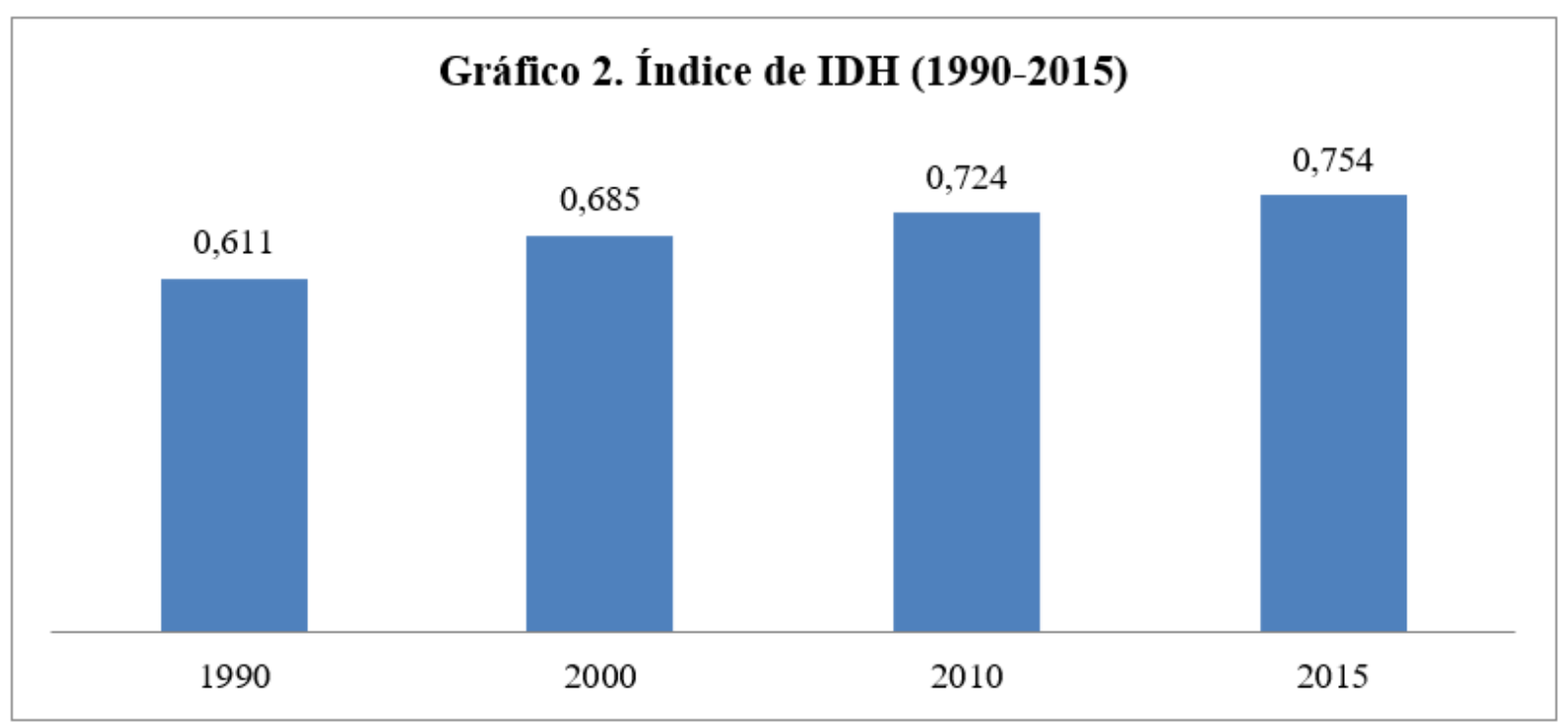

Fonte: PNUD, 2016.

De todo modo, é certo que a análise do crescimento do IDH desvinculada de demais medidores sociais é extremamente superficial para compreender a complexidade da conjuntura socioeconômica de um determinado país, haja vista que não diz nada, por exemplo, acerca das condições de emprego, circunstância extremamente valorizada em grande parte das teorias criminológicas.

Nesse sentido, o Índice de GINI é um relevante e mais preciso medidor para apontar tanto a notória redução de desigualdade social no Brasil, como para corroborar a tese de que o supracitado desenvolvimento econômico foi, em qualquer medida, conciliado com uma política de inclusão social. O gráfico a seguir (Gráfico 3), por meio da variação do Índice de GINI entre 1995 e 2012 no Brasil, indica precisamente este quadro socioeconômico brasileiro. 
Reconsiderando a tese da penalidade neoliberal inclusão social e encarceramento... Luiz Phelipe Dal Santo

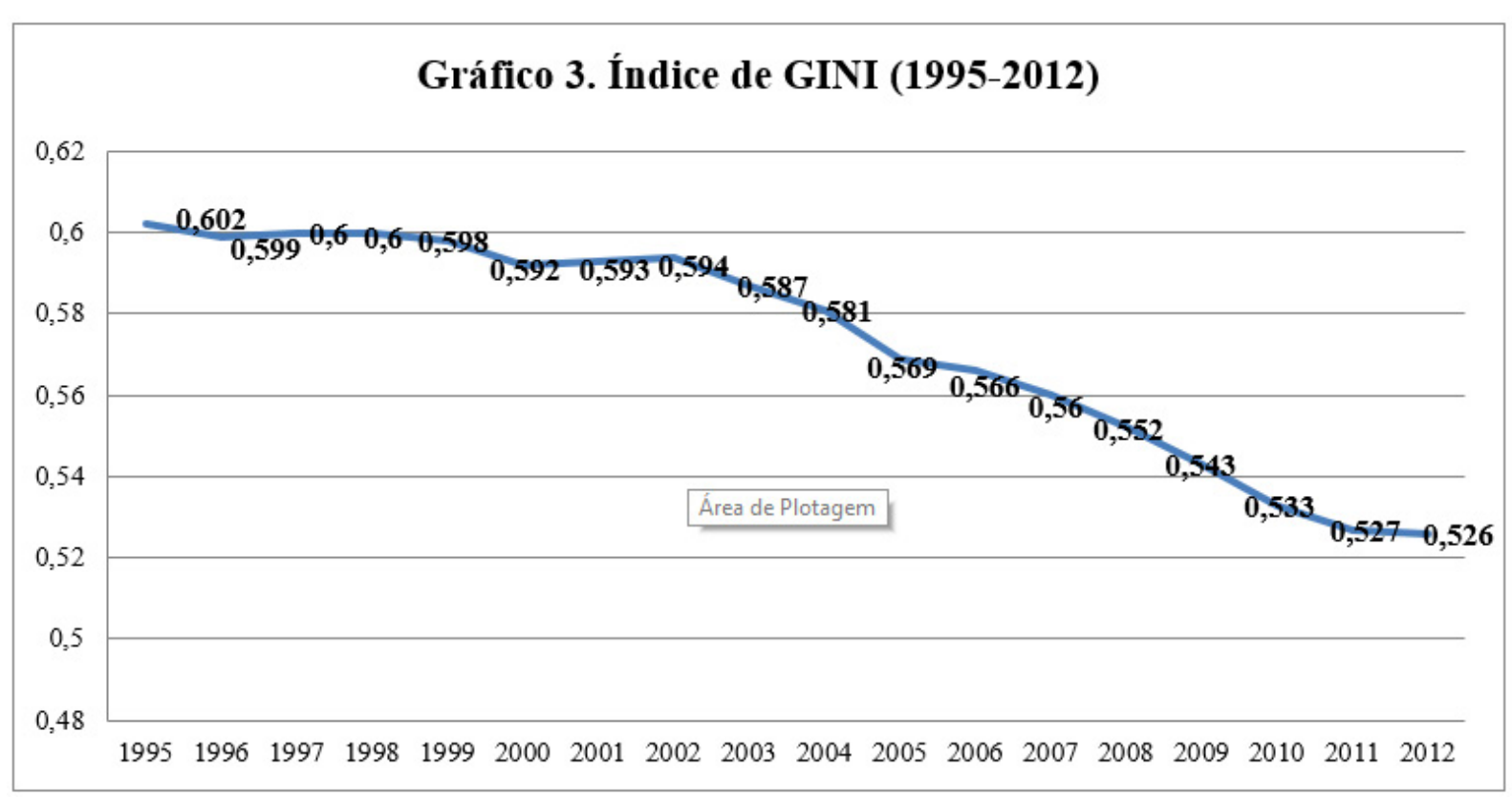

Fonte: Gráfico extraído de Azevedo e Cifali (2016).

Com efeito, observam-se basicamente duas principais tendências características deste período de ascensão econômica vinculada à inclusão social. De tal sorte, a redução de desigualdade no país demonstrada graficamente acima foi conquistada a partir da ampla redução do desemprego e da política de distribuição de renda amparada no aumento dos gastos estatais em políticas sociais, fatores estes que constituem elementos centrais nas próprias teorias da penalidade neoliberal - contudo fundamentalmente em direção contrária.

Nestes termos, é de suma relevância compreender o considerável desenvolvimento verificado no campo do trabalho. O gráfico a seguir (Gráfico 4) indica as variações nos dados oficiais sobre desemprego do Brasil, em uma frequência semestral entre junho de 2002 a dezembro de 2015. Com efeito, é facilmente notável a grande redução nos níveis de desemprego do país, que chega a alcançar 13\% em junho de 2003, sendo reduzido gradualmente desde então, para posteriormente atingir a taxa de 4,30\% em dezembro de 2013 e 2014. Ao mesmo tempo, a taxa de encarceramento variou de 222, em 2003, para 306, em 2014. 
Reconsiderando a tese da penalidade neoliberal inclusão social e encarceramento... Luiz Phelipe Dal Santo

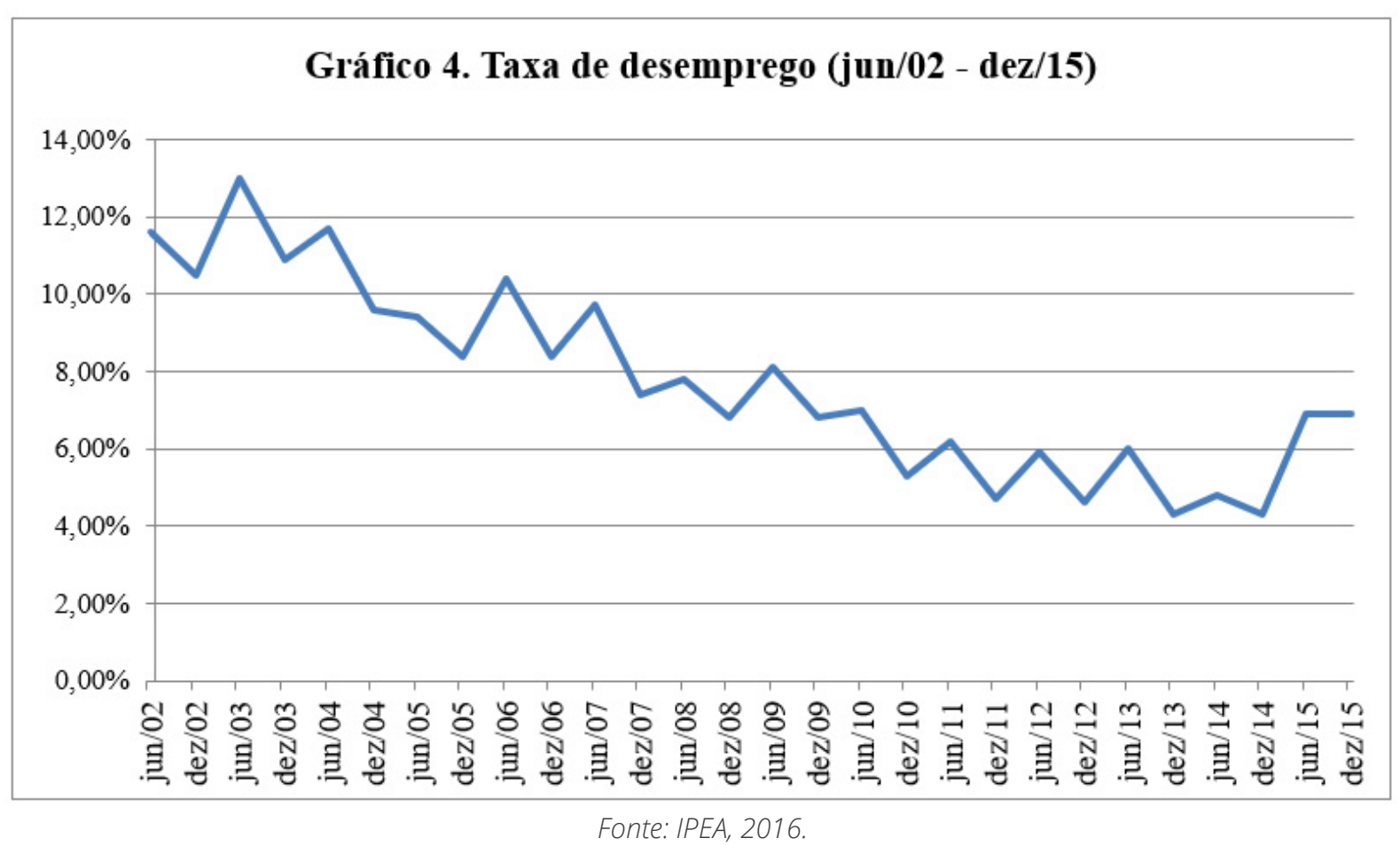

Embora já tenhamos sustentado que a simples taxa de desemprego não deve ser o único indicador da condição de vida das classes trabalhadoras, essa enorme redução de desemprego no país entre 2003 e 2014, por si só, seria capaz de enfraquecer a teoria da penalidade neoliberal enquanto teoria suficientemente satisfatória para explicar as transformações no campo penal brasileiro. Evidentemente, não se deve confundir a teoria de Loïc Wacquant (2003a), centrada na insegurança social e no caráter simbólico da punição, com a de Alessandro de Giorgi ${ }^{16}$ (2002), estabelecida a partir do controle do "excedente" ou da "subclasse", isto é, do cada vez maior grupo de pessoas permanentemente excluídos da sociedade, sequer servindo ao "exército industrial de reserva", como consequência das transformações nos modos de produção (do fordista ao pós-fordista). No entanto, se o encarceramento em massa é o modelo neoliberal de gestão da miséria, a redução do desemprego é um relevante indicador da própria redução da miséria, o que deveria produzir, ainda que em qualquer medida, uma alteração nos rumos do encarceramento.

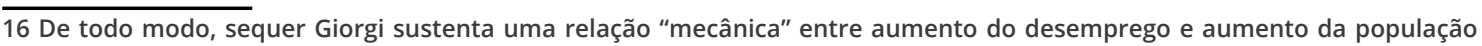
prisional. 
Reconsiderando a tese da penalidade neoliberal inclusão social e encarceramento... Luiz Phelipe Dal Santo

Ademais, o que torna este quadro ainda mais relevante é o fato de que o desemprego foi reduzido fundamentalmente por meio da criação de postos de trabalho formal, e não informal, como seria de se esperar, se seguisse a tendência pós-fordista.

Conforme analisado por Marcio Pochmann, foram criados aproximadamente 21 milhões de postos de trabalho na primeira década do século XXI, dos quais $94,8 \%$ se enquadram na base da pirâmide social brasileira, isto é, com rendimento de até 1,5 salário mínimo mensal (POCHMANN, 2012: 27). Nesse sentido, este estrato social que representava $34,3 \%$ na composição ocupacional da sociedade brasileira em 2000 passou a representar 47,8\%. Ao mesmo tempo, houve uma redução na parcela de trabalhadores sem remuneração (de 11,5\% para 10,9\%), e que também foi verificada - e de forma bastante acentuada - no estrato social com remuneração superior a cinco salários mínimo (de 16,7\% para 7,5\%) (POCHMANN: 2012; 28).

De tal sorte, este desenvolvimento indica que uma boa parte da força de trabalho nacional superou a condição de miserabilidade, no entanto, sem que isso correspondesse à ascensão à classe média. Houve, efetivamente, uma concentração na camada inferior (ou de base) da estrutura socioeconômica brasileira, correspondente à categoria de baixa remuneração.

É igualmente importante ressaltar a valorização da formalização do trabalho. Nesse sentido, a cada dez postos de trabalho de salário de base abertos na década de 2000, sete foram de empregos formais, com carteira de trabalho assinada (POCHAMNN: 2012; 38). Não por outro motivo, em 2009 o Brasil registrou a maior participação do emprego formal (com carteira assinada) no total da ocupação de salário de base em quarenta anos (POCHMANN: 2012; 40).

Ainda, destaca-se que a ampla criação de postos de trabalho formal foi devidamente acompanhada da política de valorização real do salário, o que possibilitou não apenas a ascensão social, como também aumentou a capacidade de consumo da base po- 
Reconsiderando a tese da penalidade neoliberal inclusão social e encarceramento... Luiz Phelipe Dal Santo

pular. O estímulo ao consumo, frisa-se, é um componente central neste período de inclusão social no Brasil, que parece ter pouca relação com sensos de cidadania e participação popular na vida política - isto é, nas decisões e debates públicos. Em outras palavras, a inclusão social na sociedade brasileira foi mais associada a termos de consumo do que de cidadania - formaram-se mais consumidores do que cidadãos.

Retomando o foco à questão da formação de empregos, algumas questões qualitativas sobre a intensa criação de postos de trabalho e sobre a ocupação destes trabalhos de salário de base são relevantes para dar profundidade a tal conjuntura, notadamente no que se refere às questões de raça/etnia, de sexo, etária e educacional.

Antes disso, naturalmente é necessário indicar a existência de um "perfil" do preso no Brasil: conforme informado pelo DEPEN (MINISTÉRIO DA JUSTIÇA, 2017), o preso no Brasil é majoritariamente homem $(94,2 \%)^{17}$ jovem (30\% de 18 a 24 anos e $25 \%$ de 25 a 29 anos), negro (64\%) e com baixo nível de escolaridade (96\% dos presos sequer possuem Ensino Superior Completo)

Quanto à questão étnica ou racial, vê-se uma predominância de absorção de trabalhadores não brancos nas ocupações de salário de base geradas na década de 2000 , equivalendo a $77,2 \%$ (POCHMANN: 2012; 35-36).

Em relação ao sexo, é possível notar a predominância na contratação de mulheres, que corresponderam a aproximadamente $60 \%$ das ocupações geradas para trabalhadores de salário de base nos anos 2000. No entanto, observa-se uma redução relativa se comparado à absorção das vagas de trabalho equivalentes na década de 1990, quando a ocupação feminina aos novos postos de trabalho gerados correspondia a aproximadamente $65 \%$ (POCHMANN: 2012; 32-34). Frisa-se, neste ponto, que a força de trabalho masculina continua compondo a maior parte do trabalho de salário de base, com 54,4\% em 2009 (POCHMANN:2012; 42).

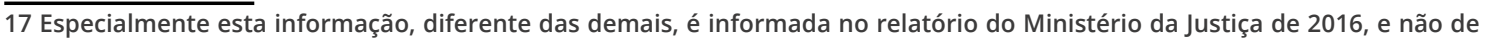
2017. 
Reconsiderando a tese da penalidade neoliberal inclusão social e encarceramento... Luiz Phelipe Dal Santo

No tocante à componente etária, identifica-se uma menor atenção ou menor amparo aos mais jovens, principalmente aqueles com menos de 25 anos. O gráfico seguinte (Gráfico 5) demonstra como as oportunidades geradas para trabalhadores de salário de base foram predominantemente ocupadas por pessoas na faixa etária superior à dos 25 anos.

De tal sorte, em que pese a primeira categoria do gráfico seguinte incorpore também os adolescentes de 14 a 17 anos, é relevante notar que tal categoria ocupou inclusive menos postos de trabalho do que pessoas de faixa etária entre 55 a 64 anos. Em direção oposta, é justamente a composição etária que inclui jovens de 18 a 24 anos a que corresponde à principal faixa etária de pessoas encarceradas, com 30\% da população carcerária.

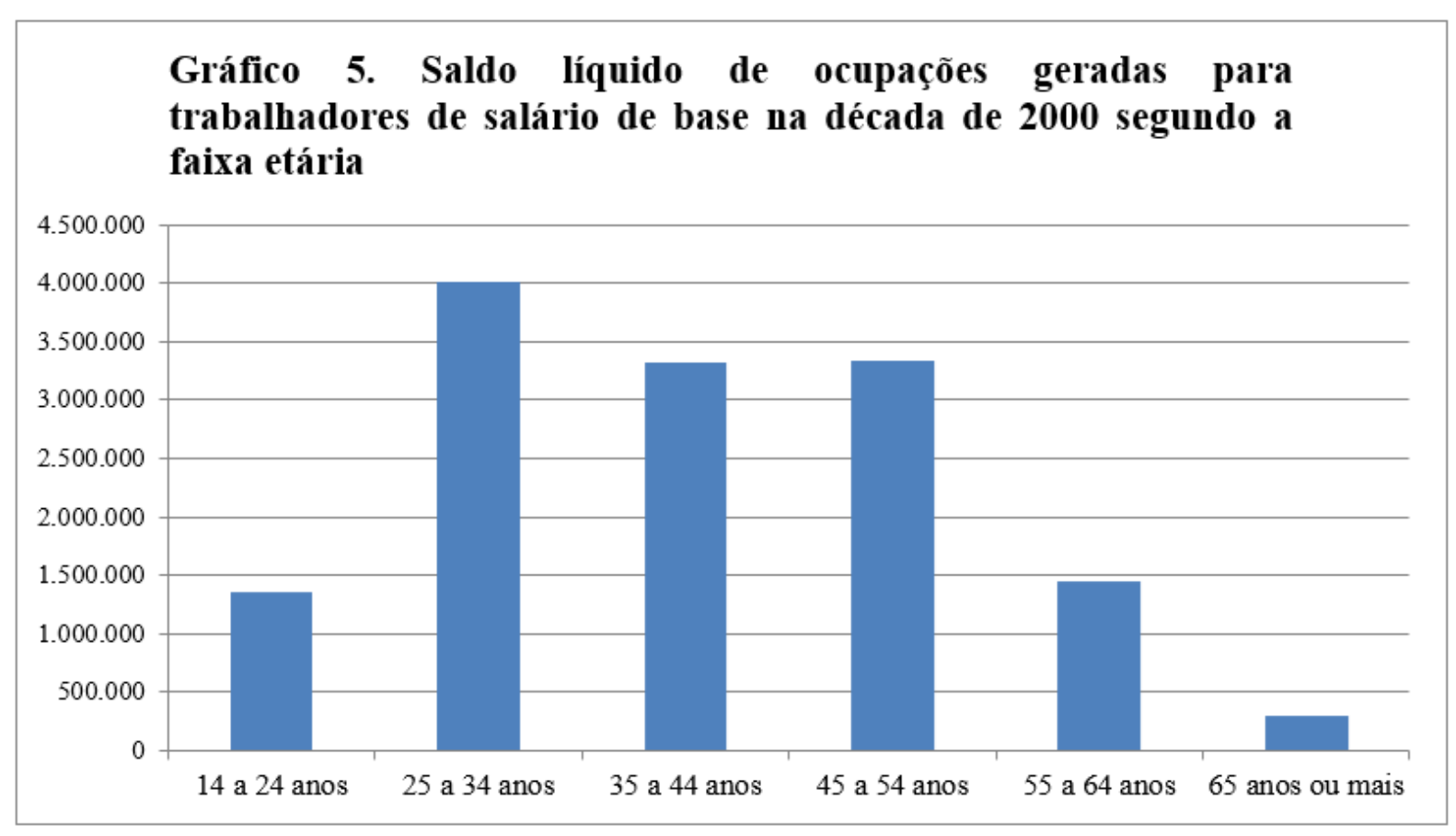

Fonte: IBGE/PNAD. Gráfico elaborado a partir de adaptações de PoCHMANN, 2012.

Esta recente tendência no campo do trabalho impactou uma considerável alteração na composição dos trabalhadores de salário de base de modo geral, envelhecendo-a, como retratado no gráfico a seguir (Gráfico 6), o qual compara tal composição aos anos de 1979 e 2009. 
Reconsiderando a tese da penalidade neoliberal inclusão social e encarceramento... Luiz Phelipe Dal Santo

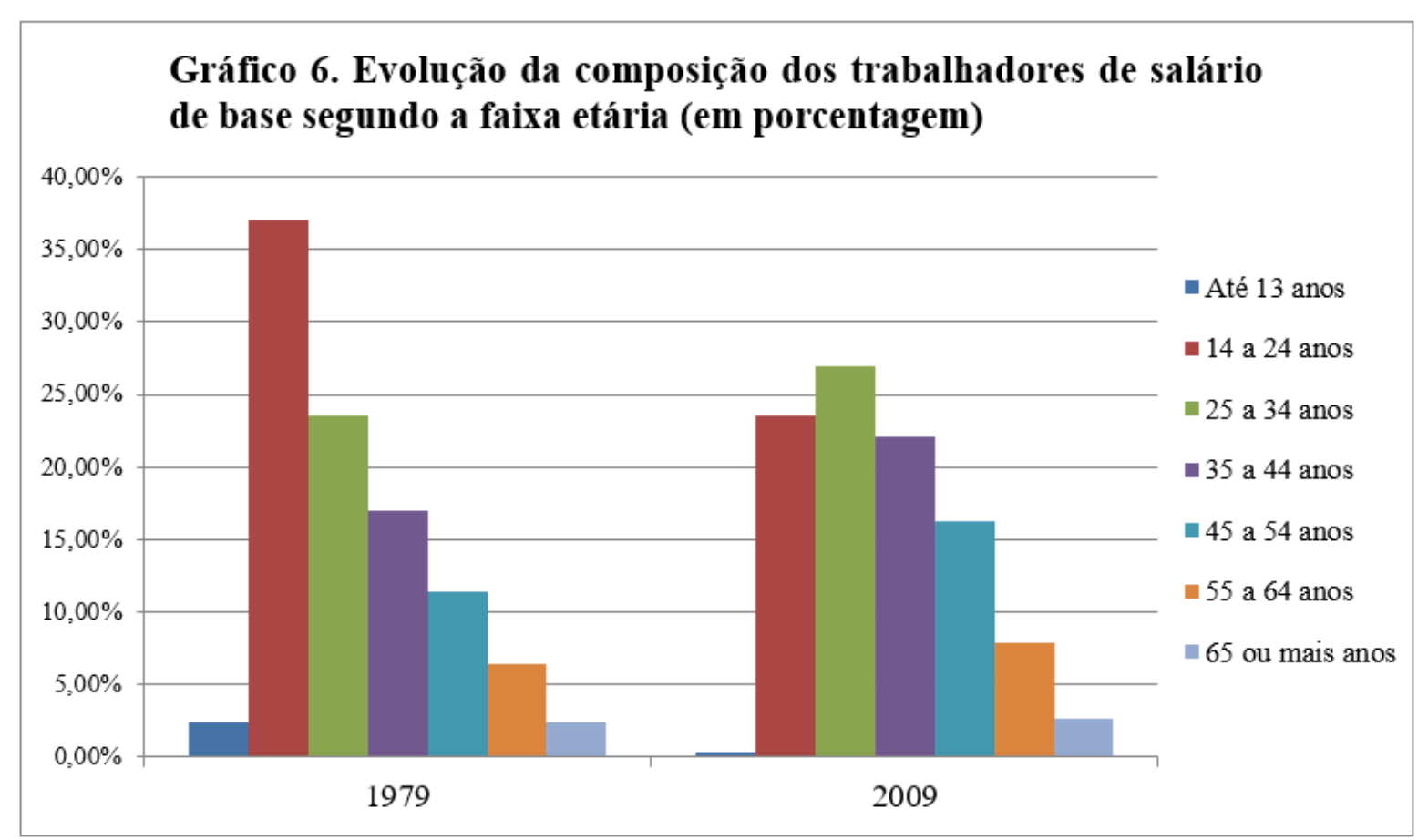

Fonte: IBGE/PNAD. Gráfico elaborado a partir de adaptações de PoCHMANN, 2012.

Aliado ao envelhecimento da força de trabalho que compõe o trabalho na base da pirâmide social brasileira, é possível notar também a qualificação - no sentido de maior grau de escolaridade - como outra tendência ocorrida no campo do trabalho brasileiro e igualmente identificada de modo geral nas teorias sobre o modelo pós-fordista de produção. Nesse sentido, Pochmann (2012: 36) observa justamente a concentração de ocupações geradas para trabalhadores de salário de base com ensino médio completo, seguida do também considerável aumento de trabalhadores com ensino superior, deixando à margem os trabalhadores com até o ensino fundamental completo - justamente o perfil das pessoas encarceradas.

De modo geral, essa grande expansão de criação de postos de trabalho de salário base influenciou fortemente uma mudança no modo de acumulação de capital na sociedade brasileira, notadamente no que se refere às rendas do trabalho e da propriedade. Se entre 1995 e 2004 o peso relativo da renda do trabalho diminuiu e a renda da propriedade teve seu peso relativo aumentado na formação total da renda nacional, esta tendência foi exatamen- 
Reconsiderando a tese da penalidade neoliberal inclusão social e encarceramento... Luiz Phelipe Dal Santo

te invertida no período entre 2004 e 2010 (POCHMANN: 2012; 9), não obstante o percentual de detentores da renda de propriedade (lucro, juros, renda da terra e aluguéis) tenha também aumentado na composição da população brasileira economicamente ativa.

Nesse sentido, o complexo crescimento econômico brasileiro vivenciado a partir do século XXI resultou em um crescimento polarizado, tanto na base (trabalho de salário base) quanto no topo (renda derivada da propriedade) da pirâmide social, conforme se observa no gráfico a seguir (Gráfico 7).

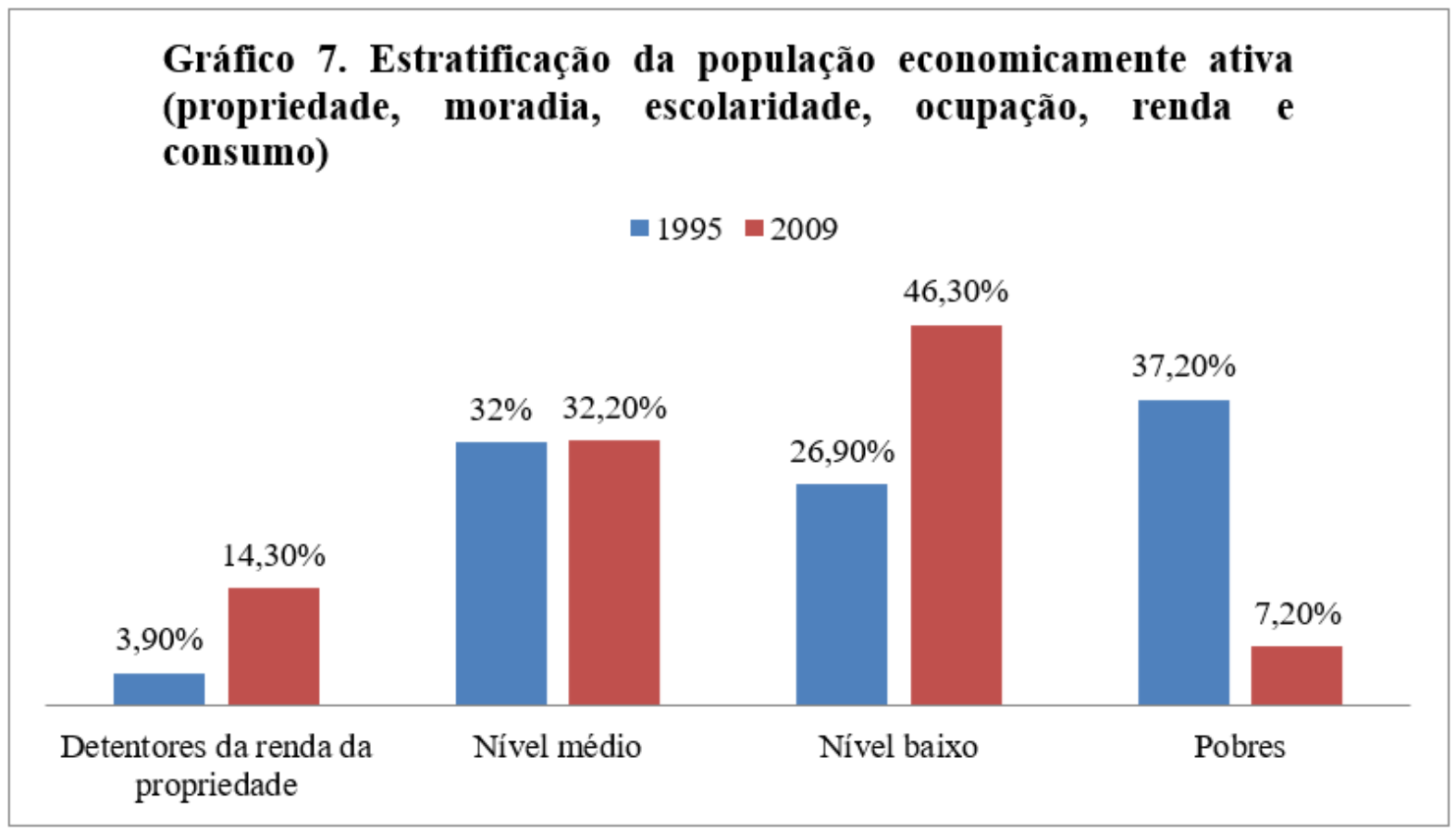

Fonte: IBGE/Censo demográfico, POF e PNAD (elaboração IPEA). Gráfico extraído e adaptado de Pochmann, 2012.

Com efeito, o quadro de ampla criação de postos de trabalho formal e de considerável redução do desemprego retratado até aqui seria suficiente para ao menos tornar necessária a análise de tal desenvolvimento socioeconômico ocorrido no país de forma paralela ao intenso crescimento da população prisional e da taxa de encarceramento brasileiras.

Um exame mais atento, no entanto, é capaz de apontar fatores que, ao invés de potencialmente conter a expansão do sistema 
Reconsiderando a tese da penalidade neoliberal inclusão social e encarceramento... Luiz Phelipe Dal Santo

penal, estariam na verdade mascarados pela mera representação numérica da ampla redução do desemprego - isto é, pela impressionante queda da taxa de desemprego, de 13\% em 2003 para 4,3\% em 2013 e 2014, especialmente limitada à questão quantitativa, mas ignorando os aspectos qualitativos.

Nestes termos, o primeiro fator que pode ser destacado é a quase inexistente alteração na porcentagem da taxa de sindicalização. Sutton (2004), por exemplo, atribui certa importância para a questão da sindicalização como um mecanismo de contenção do avanço do sistema penal. Evidentemente, seria extremamente exagerado atribuir relevância suficiente para tal conjuntura diante de um quadro de ampla redução de desemprego, como nos termos apresentados até aqui, responsável por uma grande absorção do enorme excedente de força de trabalho produzido pela ascensão do neoliberalismo nos anos 1990. De toda forma, no Brasil, embora seja notável a ocorrência de consideráveis reestruturações na base da pirâmide social brasileira e nas relações de trabalho, a taxa de sindicalização no país permaneceu praticamente imutável. Marcio Pochmann (2012; 44-46) aponta que a taxa de sindicalização do total de trabalhadores de salário base (isto é, referente especificamente à quase totalidade dos postos de trabalho criados na primeira década do século XXI) passou de 12,2\% em 1999 para 13,1\% em 2009.

Por outro lado, agora sim com extrema relevância, nota-se que justamente o perfil da população carcerária - o qual se equipara ao das vítimas da letalidade policial (DAL SANTO, 2020b) - parece não ter sido englobado pela extensa criação de postos de trabaIho. Nesse sentido, embora os postos de emprego tenham sido majoritariamente ocupados pela população não branca $(77,2 \%)$ e em grande quantidade por homens ( $40 \%$ de aproximadamente 21 milhões de empregos), há uma reduzida introdução da população jovem (de até 24 anos) ao mercado de trabalho e uma ainda menor incorporação da população com nível de escolaridade máximo equivalente ao ensino fundamental completo. Esta comparação revela, portanto, a inexistência de uma incorporação paralela dos 
Reconsiderando a tese da penalidade neoliberal inclusão social e encarceramento... Luiz Phelipe Dal Santo

jovens negros com baixo nível de educação formal pelo sistema penal e pelo mercado de trabalho, tendo sido esta categoria de indivíduos predominantemente integrada ao campo penal, permanecendo afastada do campo de trabalho. Não por outra razão, parece inexistir a suposta contradição aparentada e projetada no início do presente subcapítulo, em relação à possível grande redução do desemprego referente à população "alvo" do sistema penal.

A análise até aqui seria insuficiente para deslegitimar a compatibilidade da teoria da penalidade neoliberal à realidade brasileira. Em sentido diverso, reforçaria inclusive a ideia de uma manutenção da gestão da miséria preferencialmente por meio de políticas penais. Há, no entanto, outro componente da referida teoria que definitivamente não encontra amparo na realidade brasileira - o que não desqualifica ou anula sua construção teórica, porém limita sua aplicação ao contexto brasileiro, necessitando ao menos de adaptações irrenunciáveis na hipótese de manter tal teoria como a grande teoria explicativa das mudanças do campo penal na sociedade brasileira.

Loïc Wacquant é claro ao narrar a transição do Estado caritativo, caracterizado pelo controle da subclasse predominantemente por meio de políticas sociais, para o Estado penal, no qual passa a prevalecer o controle da subclasse pelo aparato penal do Estado, inclusive como uma política simbólica para conter a insegurança social da classe média e da elite em razão das crescentes reivindicações de direitos sociais por parte dos afroamericanos e da precarização das condições de trabalho gerada pelas transformações do sistema político-econômico.

A inclusão social no período brasileiro analisado neste tópico, conforme já indicado, não é apenas consequência do desenvolvimento econômico e da redução do desemprego - a qual deixou em segundo plano a "subclasse". Com efeito, a participação estatal foi extremamente relevante neste processo, promovendo, por exemplo, políticas de transferência de renda e, exatamente no sentido oposto da teoria de Wacquant, passando a investir mais recursos econômicos em políticas sociais, seja em números abso- 
Reconsiderando a tese da penalidade neoliberal inclusão social e encarceramento... Luiz Phelipe Dal Santo

lutos ou relativos. Ressalta-se que o desenvolvimento econômico de um país não implica necessariamente em redução da desigualdade e em inclusão social. O desenvolvimento econômico nacional desvinculado da distribuição de renda (cujo resultado é o próprio aumento da desigualdade) é não apenas possível, como fora justamente o caso na época da ditadura militar.

Antes de se analisar a variação do investimento público em políticas sociais, deve-se apresentar brevemente o capital público despendido em segurança pública neste período. Embora os gastos vinculados à segurança pública tenham crescido $68,8 \%$ em termos absolutos entre 2002 e 2015, incluindo as despesas da União, dos estados e dos municípios, a representação deste valor no PIB diminuiu de 1,47\% para 1,38\% (FBSP, 2016), não indicando a esperada "reorientação de recursos fiscais e administrativos em direção ao sistema de justiça criminal" - tal qual ocorrida nos EUA, conforme mostrado por Wacquant (2003a) -, em um período em que a taxa de encarceramento passou de 137 presos a cada cem mil habitantes para mais de 300. De todo modo, se a inexistência da reorientação de recursos (aumento relativo) ao sistema penal não permite concluir pela ocorrência de um privilégio a políticas penais em detrimento a políticas sociais, o (amplo) aumento absoluto de investimento nesta área aponta uma considerável expansão do sistema penal, o que certamente produz a ampliação de sua presença na sociedade e o esperado aumento nos números de encarceramento, conforme indicado por Fonseca (2017).

Por outro lado, em relação ao investimento público em políticas sociais, pode-se inicialmente dar algum destaque ao papel do Estado brasileiro na criação de um programa de investimento habitacional, iniciado em 2009. No segundo tópico, indicou-se ironicamente que a política de construção de novos presídios tinha se tornado o principal programa habitacional dos Estados Unidos a partir do encarceramento em massa. No Brasil, o programa Minha Casa Minha Vida, criado em 2009, deu início à construção de aproximadamente um milhão de unidades habitacionais destinadas à população de baixa renda entre 2009 e 2010 (BARBOSA: 2013; 
Reconsiderando a tese da penalidade neoliberal inclusão social e encarceramento... Luiz Phelipe Dal Santo

83), constituindo um programa de proteção e acesso à moradia de ampla dimensão para os setores mais pobres da população brasileira, até então historicamente restritos e contidos nas favelas.

Outra importante política social verificada no Brasil reside no campo da educação. De modo geral, os gastos estatais em educação e cultura passaram de 1,7\% do PIB em 2002 para 2,7\% do PIB em 2015, incluindo gastos diretos e tributários (BRASIL: 2016; 10). Quando transformado em números absolutos, este crescimento relativo do investimento em educação e cultura representa um salto de $\mathrm{R} \$ 57.000 .000 .000,00$ em 2002 para $\mathrm{R} \$ 160.000 .000 .000,00$ em 2015 (BRASIL: 2016; 19).

De modo específico, pode-se destacar um projeto de democratização e ampliação do acesso ao ensino superior, especialmente por meio do Programa Universidade para Todos (Prouni), criado em 2005. Este programa, destinado aos egressos do ensino médio em situação de pobreza, prevê a concessão de bolsas integrais e parciais (de 50\%) de estudo em instituições privadas de ensino superior, tanto em cursos de graduação, quanto em cursos sequenciais de formação específica. Conforme notado por Gentili e Oliveira (2013: 255-256), desde sua criação até 2012, o Prouni atingiu quase 1,5 milhão de estudantes, dos quais mais da metade foram contemplados com bolsa integral. Ademais, neste mesmo período, é possível verificar um crescimento anual no número de bolsas ofertadas.

Por fim, há que se destacar a evolução dos gastos federais especificamente com assistência social. Em termos relativos, o investimento público em assistência social (considerando gastos diretos e tributários) representava $0,47 \%$ do PIB em 2002, passando para 1,54\% do PIB em 2015 (BRASIL: 2016; 15), mais do que triplicando em termos relativos. Já em termos absolutos, estes números representam $R \$ 15.900 .000 .000,00$ em 2002 e $R \$ 91.300 .000 .000,00$ em 2015 (BRASIL: 2016; 15).

No âmbito da assistência social, o principal programa criado pelo governo brasileiro é o Bolsa Família, um programa de trans- 
Reconsiderando a tese da penalidade neoliberal inclusão social e encarceramento... Luiz Phelipe Dal Santo

ferência de renda destinado ao combate à pobreza instituído em 2004. Em seu ano inicial, o Bolsa Família consumia 0,29\% do PIB, passando para 0,45\% do PIB em 2015 (BRASIL: 2016; 17). Apontase que, já em 2009, este programa beneficiava monetariamente quase 50 milhões de pessoas em condição de pobreza ou extrema pobreza, sendo estas majoritariamente negras (PAIXÃO et. al.: 2010; 133-138). A expansão do alcance de tal programa também é extremamente considerável. Em 2005, relata-se que aproximadamente 8,7 milhões de famílias eram atingidas pelo Bolsa Família (BARBOSA: 2013; 74). Dez anos depois, o número de beneficiados incluía quase 14 milhões de famílias ${ }^{18 .}$

De modo geral, é possível sustentar que, embora o perfil da "clientela" do sistema penal não tenha sido efetivamente englobado pela ampla criação de postos (formais) de trabalho no século $X X I$, este perfil social é justamente contemplado pela igualmente ampla política pública de transferência de renda e combate à pobreza, destinada "particularmente [a]os setores mais pauperizados que normalmente dependiam das benesses do Estado para sobreviver" (ANTUNES: 2015: 10).

Nestes termos, a teoria da penalidade neoliberal encontra uma conjuntura extremamente distinta no Brasil do século XXI, onde se pôde verificar um considerável desenvolvimento social, inclusive por meio de programas estatais de inclusão social e distribuição de renda, redução do desemprego, criação de postos de trabalho formal e redução da desigualdade social. Não por outro motivo, parece mais adequada a ideia de que não basta mais insistir na questão da penalidade neoliberal (CHELIOTIS; XENAKI: 2010; BRANDARIZ GARCÍA; SOZZO: 2014; O'MALLEY: 2015; SOZZO: 2017; Dieter; Dal Santo: 2017; Dal Santo: 2018). A complexidade das transformações no campo de controle do crime no Brasil e as particularidades políticas, sociais e econômicas do país sul-americano exigem pesquisas mais aprofundadas, que não deixem de analisar as relações globais vinculadas às estratégias de controle do crime, mas que se atentem também às peculiaridades locais,

18 Disponível em: http://mds.gov.br/area-de-imprensa/noticias/2015/marco/bolsa-familia-beneficia-quase-14-milhoes-de-familias-em-marco. Acesso em: 12 dez. 2017. 
Reconsiderando a tese da penalidade neoliberal inclusão social e encarceramento... Luiz Phelipe Dal Santo

o que inclui aspectos políticos, jurídicos, institucionais, culturais e socioeconômicos.

\section{Considerações finais}

Embora responda melhor à realidade de certos países centrais do capitalismo, a tese da penalidade neoliberal merece ser reconsiderada quando aplicada para dar conta de explicar o desenvolvimento das tendências de punição na realidade brasileira.

Ainda que não seja o elemento mais crítico da questão, seu próprio ponto de partida seria problemático em relação ao Brasil, na medida em que tal teoria pressupõe a transição de um Estado social (Welfare State) para o Estado (neoliberal e) penal. Nesse contexto, enquanto os países europeus e os Estados Unidos tiveram de fato uma experiência "welfarista", no Brasil, vivia-se sob um regime de ditadura militar, extremamente punitivo e autoritário, onde prisões ilegais e arbitrárias, tortura, desaparecimento de mortos políticos e censura caracterizavam um terrorismo de Estado. De toda forma, não é apenas o período "pré" neoliberal que efetivamente desvalida tal teoria. O maior obstáculo para a utilização da penalidade neoliberal como teoria que suficientemente explica as transformações no campo penal brasileiro é justamente a existência de um período "pós" neoliberal - ao menos em relação às características centrais do "neoliberalismo realmente existente" de Wacquant.

Há quem considere o desenvolvimento social no Brasil (e na América Latina de modo geral) indicado no presente artigo como conjuntural e reformista, sem qualquer ruptura estrutural com o modelo neoliberal. Nessa hipótese, haveria um funcionamento do Estado Penal em conjunto com políticas assistencialistas (BRANDARIZ GARCÍA; BOZZA: 2014; 176). Em sentido diverso, os dados aqui apresentados indicam não apenas um grande desenvolvimento econômico conciliado com inclusão social e redução da 
Reconsiderando a tese da penalidade neoliberal inclusão social e encarceramento... Luiz Phelipe Dal Santo

desigualdade, como também atestam a significativa participação do Estado brasileiro na constituição de tal processo. De tal sorte, não obstante seja possível observar um incremento absoluto do investimento público em segurança pública, a "reorientação dos recursos públicos" privilegiando políticas penais em detrimento de políticas sociais, como elemento central da obra de Loïc Wacquant, não é verificada na recente história brasileira. Em realidade, o aumento do investimento público em políticas sociais inclusive é proporcionalmente maior do que em políticas penais, embora isso não tenha impactado qualquer alteração no ritmo de crescimento acelerado da população prisional e da taxa de encarceramento brasileiras. Aqui reside o elemento mais controvertido da eventual ocorrência da penalidade neoliberal no Brasil, sendo o suficiente para reconhecer que a ascensão do neoliberalismo não deve ser a única preocupação dos criminólogos que pesquisam e estudam o "giro punitivo", uma vez que a obsessão com tal "fator causal" tende a ocultar outros fatores locais que também produzem transformações no campo da penalidade.

O neoliberalismo certamente tem sua relevância na observada tendência global de expansão do sistema penal, notadamente no início de tal processo. No entanto, os motivos alegados no presente artigo são razoavelmente suficientes para inverter a lógica investigativa. Não se trata mais de insistir na questão da penalidade neoliberal, procurando sistematicamente adaptar uma conjuntura (local) a uma teoria preconcebida (supostamente global). O caminho deve ser justamente o inverso. As contradições e incompatibilidades da penalidade neoliberal em relação à época de inclusão social na realidade brasileira nos levam a questionar precisamente o porquê da continuidade do desenvolvimento do sistema penal na mesma direção percorrida no período anterior às recentes transformações socioeconômicas vivenciadas no Brasil do século XXI. 
Reconsiderando a tese da penalidade neoliberal inclusão social e encarceramento... Luiz Phelipe Dal Santo

\section{Referências}

Alexander. Michelle. The new Jim Crow: Mass Incarceration in the Age of Colorblindness. New York: Jackson, Tenn: New Press; Distributed by Perseus Distribution, 2010.

Anderson, Perry. Balanço do neoliberalismo. In Sader, Emir; Gentili, Pablo [org.]. Pós-neoliberalismo: as políticas sociais e o Estado democrático. Rio de Janeiro: Paz e Terra, 1995, p. 9-23. Antunes, Ricardo. A desertificação neoliberal no Brasil (Collor, FHC e Lula). 2.ed. Campinas: Autores Associados, 2005.

Antunes, Ricardo. Adeus ao trabalho?: ensaio sobre as metamorfoses e a centralidade do mundo do trabalho. 11.ed. São Paulo: Cortez; Campinas: Universidade Estadual de Campinas, 2006.

Antunes, Ricardo. "Inglaterra e Brasil: duas rotas do social-liberalismo em duas notas". Currículo sem Fronteiras, 13: 2, p. 204212, maio/agosto, 2013.

Antunes, Ricardo. "Fenomenologia da crise brasileira". Lutas sociais, São Paulo, 19: 35, p. 09-26, julho/dezembro, 2015.

Azevedo, Rodrigo; Cifali, Ana Claudia. Seguridad pública, política criminal y penalidad en Brasil durante los gobiernos Lula y Dilma (2003-2014). Cambios y continuidades. In: Sozzo, Máximo [org.]. Postneoliberalismo y penalidad en América del Sur [recurso digital]. Buenos Aires: CLACSO, 2016.

Barbosa, Nelson. Dez anos de política econômica. In: Sader, Emir [org.]. 10 anos de governos pós-neoliberais no Brasil: Lula e Dilma. São Paulo: Boitempo; Rio de Janeiro: FLACSO, p. 69-103, 2013.

Beckett, Katherine; Western, Bruce. "Governing social marginality: welfare, incarceration, and the transformation of State policy". Punishment \& Society, 3: 1, p. 43-59, January, 2001. 
Reconsiderando a tese da penalidade neoliberal inclusão social e encarceramento... Luiz Phelipe Dal Santo

Bell, Emma. Criminal Justice and neoliberalism. Basingstoke: Palgrave Macmillan, 2011.

Bell, Emma. "Insistiendo en el neoliberalismo: la permanente influencia del neoliberalismo en la penalidad contemporánea". Trad. José Ángel Brandariz. Delito y Sociedad, 23: 38, p. 50-62, 2014.

Brandariz García, José Angel; Melossi, Dario; Sozzo, Máximo. The Political Economy of Punishment Today: an introduction. In Melossi, Dario; Sozzo, Máximo; Brandariz García, José Angel [org.]. The political economy of punishment today: visions, debate and challenges. London: Routledge, p. 1-22, 2017.

Brandariz García, José Ángel; Bozza, Fábio. “Repensando a crítica do sistema penal no tempo da great recession". Revista Justiça e Sistema Criminal, 6: 10, 2014, p. 167-182.

Brandariz García, José Ángel; Sozzo, Máximo. "Beyond Neoliberalism? A critical reading of the uses of this concept to think about contemporary transformations of penality", European Group for the Study of Deviance and Social Control 42th Annual Conference: Resisting the demonisation of 'the Other': State, nationalism and social control in a time of crisis, Liverpool, England, September 2014.

Brasil. Gasto Social do Governo Central 2002 a 2015. Brasília: Secretaria do Tesouro Nacional, 2016. Disponível em: http:// www.tesouro.fazenda.gov.br/documents/10180/318974/ Gasto+Social+Governo+Central/c4c3d5b6-8791-46fb-b5e9-57a016db24ec. Acesso em: 10 ago. 2018

Bourdieu, Pierre; Wacquant, Loïc. "Sobre as artimanhas da razão imperialista". Estudos afro-asiáticos, 24: 1. Rio de Janeiro, 2002.

Cavadino, Michael; Dignan, James. "Penal policy and political economy". Criminology \& Criminal Justice, 6: 4, 2006, p. 435-456. 
Reconsiderando a tese da penalidade neoliberal inclusão social e encarceramento... Luiz Phelipe Dal Santo

Cavadino, Michael; Dignan, James. Penal comparisons: puzzling relations. In: Crawford, A. [org.]. International and comparative criminal justice and urban governance: convergence and divergence in global, national and local settings. Cambridge: Cambridge University Press, 2011, p. 193-213.

Cheliotis, Leonidas; Xenakis, Sappho. "What's neoliberalism got to do with it? Towards a political economy of punishment in Greece". Criminology and Criminal Justice, 10: 4, 2010, p. 353-373.

Chomsky, Noam. O lucro ou as pessoas? Neoliberalismo e a ordem global. 5.ed. Tradução. Pedro Jorgensen Jr. Rio de Janeiro: Bertrand Brasil, 2006.

Dal Santo, Luiz Phelipe. "Racismo e controle social no Brasil: história e presente do controle do negro por meio do sistema penal". Revista Brasileira de Ciências Criminais, vol. 138, ano 25, p. 269-303. São Paulo: Ed. RT, dez. 2017.

Dal Santo, Luiz Phelipe. Prospettiva postcoloniale sulla economia politica della pena: la svolta punitiva in Brasile. Dissertação (Mestrado em Criminologia Crítica e Segurança Social) - Università degli Studi di Padova: Pádua; Università di Bologna: Bolonha, 2018.

Dal Santo, L.P. ‘Cumprindo pena no Brasil: encarceramento em massa, prisão-depósito e os limites das importações teóricas sobre giro punitivo na realidade periférica'. Revista Brasileira de Ciências Criminais, v. 151, 2019, p. 291-315.

Dal Santo, Luiz Phelipe. ‘Populismo penal: o que nós temos a ver com isso?'. Revista Brasileira de Ciências Criminais, v. 168, 2020a, p. 225-252.

Dal Santo, Luiz Phelipe. 'Uma outra pena de morte: a violência letal do sistema penal brasileiro'. Revista Direito, Estado e Sociedade, v. 56, 2020b, p. 167-197.

Dieter, Vitor; Dal Santo, Luiz Phelipe. "From warehousing to the organization of crime". Common Study Programme on Criminal 
Reconsiderando a tese da penalidade neoliberal inclusão social e encarceramento... Luiz Phelipe Dal Santo

Justice and Critical Criminology: New terrorism, new punitiveness and human rights?, Corinth, Greece, November, 2017.

ESPING-ANDERSEN, Gøsta. The three worlds of welfare capitalism. Cambridge: Polity Press, 1990.

Fonseca, David. "Expansion, standardization, and densification of the criminal justice apparatus: recent developments in Brazil". Punishment \& Society, March-01-2017.

Foucault, Michel. Nascimento da biopolítica: curso dado no Collège de France (1978-1979). Tradução Eduardo Brandão. Martins Fontes: São Paulo, 2008.

Foucault, Michel. Microfísica do poder. 28.ed. Rio de Janeiro: Paz e Terra, 2014.

Gentili, Pablo; Oliveira, Dalila Andrade. A procura da igualdade: dez anos de política educacional no Brasil. In: Sader, Emir [org.]. 10 anos de governos pós-neoliberais no Brasil: Lula e Dilma. São Paulo: Boitempo; Rio de Janeiro: FLACSO, 2013, p. 253-263. Giorgi, Alessandro de. Zero tolleranza: strategie e pratiche della società di controllo. Roma: DeriveApprodi, 2000.

Giorgi, Alessandro de. Il governo dell'eccedenza: postfordismo e controllo della moltitudine. Verona: Ombre Corte, 2002.

Giorgi, Alessandro de. "Castigo y economía política". Delito y sociedad, 25: 41, 2016a.

Giorgi, Alessandro de. Il razzismo strutturale e "colorblind" degli Stati Uniti d'America. In Associazione Società INformazione. Rapporto sui diritti globale. Roma: Ediesse, 2016b.

HALL, Peter; SOSKICE, David. An introduction to the varieties of capitalism. In: HALL, Peter; SOSKICE, David [org.] Varieties of capitalism. Oxford: Oxford University Press, 2003, p. 1-68.

Harcourt, Bernard. The Illusion of Free Markets: Punishment and the Myth of Natural Order. Cambridge: Harvard University Press, 2011. 
Reconsiderando a tese da penalidade neoliberal inclusão social e encarceramento... Luiz Phelipe Dal Santo

Harvey, David. 0 neoliberalismo: história e implicações. Trad. Adail Sobral e Maria Stela Gonçalves. São Paulo: Loyola, 2008. Instituto Brasileiro de Geografia e Estatística (IBGE). Estatísticas do século XX. Rio de Janeiro: IBGE, 2006. Disponível em: https:// seculoxx.ibge.gov.br/images/seculoxx/seculoxx.pdf. Acesso em: 20 fev. 2017.

Instituto de Pesquisa Econômica Aplicada (IPEA). Taxa de desemprego: mensal de 2002.03 até 2015.12. [recurso digital]. IBGE/ PME, 2016. Disponível em: http://www.ipeadata.gov.br/exibeserie.aspx?serid=38401. Acesso em: 09 ago. 2018

Lacey, Nicola. The prisoners' dilemma: political economy and punishment in contemporary democracies. Cambridge: Cambridge University Press, 2008.

Lacey, Nicola. Punishment, (Neo)Liberalism and Social Democracy. In Simon, Jonathan; Sparks, Richard (eds.). The SAGE Handbook of Punishment and Society. Londres: SAGE Publications, 2013, p. 260-280.

Martins, Carlos Eduardo. Neoliberalismo e desenvolvimento na América Latina. In: Estay Reyno, Jaime [org.]. La economía mundial y América Latina: tendencias, problemas y desafíos. Buenos Aires: CLACSO, 2005, p. 139-167.

Martins, Carlos Eduardo. Globalização, dependência e neoliberalismo na América Latina. São Paulo: Boitempo, 2011.

Melossi, Dario; Pavarini, Massimo. Cárcere e Fábrica: as origens do sistema penitenciário (séculos XVI - XIX). Tradução Sérgio Lamarão. 2.ed. Rio de Janeiro: Revan, 2010.

Ministério da Justiça. Dez anos da política nacional de penas e medidas alternativas. Brasília: CONAPA, 2010.

Ministério da Justiça. Levantamento nacional de informações penitenciárias. Infopen - dezembro, 2014. Brasília: DEPEN, 2016. 
Reconsiderando a tese da penalidade neoliberal inclusão social e encarceramento... Luiz Phelipe Dal Santo

Ministério da Justiça. Levantamento nacional de informações penitenciárias. Infopen - junho, 2016. Brasília: DEPEN, 2017. Netto, José Paulo; Braz, Marcelo. Economia política: uma introdução crítica. São Paulo: Cortez, 2006.

O'Malley, Pat. "Repensando la penalidad neoliberal". Delito y sociedad, Santa Fé, 24: 40, 2015, p. 11-30.

Paixão, Marcelo; Rossetto, Irene; Montovanele, Fabiana; Carvano, Luiz. Relatório Anual das Desigualdades Raciais no Brasil; 2009-2010: Constituição Cidadã, seguridade social e seus efeitos sobre as assimetrias de cor ou raça. Rio de Janeiro: Garamond, 2010. Disponível em: http://www.palmares.gov.br/wp-content/ uploads/2011/09/desigualdades_raciais_2009-2010.pdf. Acesso em: 16 mai. 2017.

Pavarini, Massimo. "Uno sguardo ai processi di carcerizzazione nel mondo: da 'La Rond dei carcerati' al 'Giromondo penitenziario"'. Rassegna penitenziaria e criminologia, n. 1-2, 2002, p. 105-126.

Pochmann, Marcio. Nova Classe média? O trabalho na base da pirâmide social brasileira. São Paulo: Boitempo, 2012.

Rusche, Georg; Kirchheimer, Otto. Punição e estrutura social. Traduzione Gizlene Neder. 2.ed. Rio de Janeiro: Revan, 2004.

Sader, Emir. A construção da hegemonia pós-neoliberal. In: Sader, Emir [org.]. 10 anos de governos pós-neoliberais no Brasil: Lula e Dilma. São Paulo: Boitempo; Rio de Janeiro: FLACSO, 2013, p. 135-143.

Sozzo, Máximo. "Más allá de la tesis de la penalidad neoliberal? Giro punitivo y cambio político en América del Sur". Revista Brasileira de Ciências Criminais, São Paulo, 25: 129, 2017a, p. 321-348.

Sozzo, Máximo. The renaissance of the political economy of punishment from a comparative perspective. Melossi, Dario; Sozzo, Máximo; Brandariz García, José Angel [org.]. The political econ- 
Reconsiderando a tese da penalidade neoliberal inclusão social e encarceramento... Luiz Phelipe Dal Santo

omy of punishment today: visions, debate and challenges. London: Routledge, 2017b, p. 36-64.

Sutton, John. "The political economy of imprisonment in affluent western democracies, 1960-1990". American sociological review, vol. 69, April 2004, p. 170-189.

Wacquant, Loïc. As prisões da miséria. Rio de Janeiro: Jorge Zahar, 2001.

Wacquant, Loïc. Punir os pobres: a nova gestão da miséria nos Estados Unidos. Tradução Eliana Aguiar. 2.ed. Rio de Janeiro: Revan, 2003a.

Wacquant, Loïc. "Toward a dictatorship over the poor? Notes on the penalization of poverty in Brasil". Punishment \& Society, 5: 2, 2003b, p. 197-205.

Wacquant, Loïc. "La militarizzazione della marginalità urbana: lezioni dalla metropoli brasiliana". Studi sulla questione criminale. 3/2006, 2006, p. 7 - 30.

Wacquant, Loïc. "Três etapas para uma antropologia histórica do neoliberalismo realmente existe". Caderno CRH, 25: 66, set./dez., 2012, p. 505-518.

Wacquant, Loïc. Iperincarcerazione: neoliberismo e criminalizzazione della povertà negli Stati Uniti. Giorgi, Alessandro de [org.]. Verona: Ombre corte, 2013.

Wacquant, Loïc. “Bourdieu, Foucault e o Estado penal na era neoliberal". Revista Transgressões: ciências criminais em debate. Natal, 3: 1, 2015, p. 5-22.

Wilson, James; Kelling, George. "Broken Windows: the police and neighbourhood safety". Atlantic Monthly, 1982, p. 29-38. 